\title{
Phosphorus deficiency enhances water deficit impact on some morphological and physiological traits in four faba bean (Vicia faba L.) varieties
}

\author{
Khawla Oukaltouma, ${ }^{1,2}$ Ahmed El Moukhtari, ${ }^{1}$ Yahya Lahrizi, ${ }^{1}$ Mohammed Mouradi, ${ }^{3}$ \\ Mohamed Farissi, ${ }^{3}$ Anne Willems, ${ }^{4}$ Ahmed Qaddoury, ${ }^{1}$ Faouzi Bekkaoui, ${ }^{2,5}$ Cherki Ghoulam ${ }^{1,2}$ \\ ${ }^{1}$ Team of Biotechnology and Symbiosis Agrophysiology, Faculty of Sciences and Techniques, UCA, \\ Marrakech, Morocco; ${ }^{2}$ Agrobiosciences Program, Mohamed VI Polytechnic University, Benguerir, \\ Morocco; ${ }^{3}$ Laboratory of Biotechnology and Sustainable Development of Natural Resources (B2DRN), \\ Polydisciplinary Faculty, USMS, Beni Mellal, Morocco; ${ }^{4}$ Laboratory of Microbiology, Faculty of Sciences, \\ Ghent University, Ghent, Belgium; ${ }^{5}$ National Institute of Agronomic Research (INRA), Rabat, Morocco
}

\section{Highlights}

- Varieties tolerant to low phosphorus and water deficiency are needed in arid and semi-arid regions with low $P$.

- Phosphorus nutrition is advantageous for mitigating the effect of water deficit on faba bean (Vicia faba) plants and conversely, deficient $P$ supply reduces resilience to water deficit.

- The faba bean variety Aguadulce showed high tolerance to the combined effect of water deficit and phosphorus deficiency in terms of growth, leaf water potential, stomatal conductance, membrane permeability and glycine betaine accumulation.

Reina Mora was the least tolerant variety to water deficit combined with P limitation.

- Combined limitation of water and phosphorus induced accumulation of glycine betaine in leaves.

\begin{abstract}
Moroccan soils, generally present low available phosphorus (P) levels which occur in almost all arid and semi-arid regions. Faba bean is one of the most significant crops in Morocco and is
\end{abstract}

Correspondence: Cherki Ghoulam, Team of Biotechnology and Symbiosis Agrophysiology, Faculty of Sciences and Techniques, UCA, Marrakech, Morocco.

E-mail: c.ghoulam@uca.ma

Key words: Drought; glycine betaine; growth; legume; osmoregulation; phosphorus; water potential.

Acknowledgements and funding: the authors would like to acknowledge the financial support from the Moroccan-Belgium cooperation project VLIRUOS (SI), project No. MA2018S1N2254103. The authors sincerely thank Diana Bekkaoui for the English editing and the review of the manuscript.

Conflict of interests: the authors declare no potential conflict of interests.

Received for publication: 2 June 2020.

Revision received: 14 August 2020.

Accepted for publication: 22 September 2020.

${ }^{\circ}$ Copyright: the Author(s), 2021

Licensee PAGEPress, Italy

Italian Journal of Agronomy 2021; 16:1662

doi:10.4081/ija.2020.1662

This article is distributed under the terms of the Creative Commons Attribution Noncommercial License (by-nc 4.0) which permits any noncommercial use, distribution, and reproduction in any medium, provided the original author(s) and source are credited. influenced by these constraints that affect its nutrient uptake and nitrogen fixation capacity and hence plants development. Therefore, we evaluated the response of four Vicia faba varieties Aguadulce (Ag), Alfia (Al), Luz de Otono (LO) and Reina Mora (RM) -, grown under biological nitrogen fixation to water deficit and two phosphorus levels. The trial was conducted under greenhouse conditions and water stress was induced by keeping pots at $40 \%$ substrate field capacity (FC) versus $80 \%$ FC for the controls while phosphorus deficiency treatment consisted in the application of $25 \mu \mathrm{mol} \mathrm{P}$ plant $^{-1}$ week $^{-1}$ versus $125 \mu \mathrm{mol} \mathrm{P}$ plant $^{-1}$ week $^{-1}$ for sufficient $\mathrm{P}$ treatment. The results revealed a significant effect of water deficit and phosphorus deficiency either alone or combined on plants dry weights, leaf water parameters and nutrient concentrations. However sufficient phosphorus supply mitigated the adverse effects of water deficit on faba bean. We noticed significant differences between the studied varieties. Ag showed high performance concerning dry weights $(1.25 \mathrm{~g}$ and $1.88 \mathrm{~g} \mathrm{plant}^{-1}$ respectively for shoot and root) and high concentration of nitrogen $\mathrm{N}(4.7 \%)$ and $\mathrm{P}\left(0.27 \mathrm{mg} \mathrm{g}^{-1} \mathrm{DW}\right)$ and was then qualified as the most tolerant variety to water deficit combined with P limitation. While RM was the least tolerant variety, as it showed the lowest dry weights $\left(0.51 \mathrm{~g}\right.$ and $1.4 \mathrm{~g} \mathrm{plant}^{-1}$ respectively for shoot and root) and concentration $(2.74 \%$ and $0.19 \mathrm{mg}$ $\mathrm{g}^{-1} \mathrm{DW}$ respectively for $\mathrm{N}$ and $\left.\mathrm{P}\right)$. The tolerance was related to the ability to ensure efficient osmoregulation by glycine betaine accumulation, to keep leaf water balance and cell membrane stability that contribute together with adequate symbiotic nitrogen fixation to plant growth performance under combined stresses.

\section{Introduction}

Faba bean (Vicia faba L.) cultivated land worldwide was 3.7 million ha by 1980 and declined to 2.1 million ha by 2014 (FAO, 2017). The inclusion of faba bean in human and animal diets has 
health benefits because it presents a high protein content and is a source of several nutrients including $\mathrm{Fe}, \mathrm{Mg}, \mathrm{Zn}, \mathrm{K}$ and $\mathrm{Ca}$, amino acids, carbohydrates, vitamins and essential nutraceuticals (Multari et al., 2015; Koivunen et al., 2016). The addition of pulse crops such as faba beans, in rotation with cereals, improves soil: physical, chemical, and biological properties, soil fertility, disturbs pest and disease cycles and reduces the use of inorganic nitrogen fertilizer through the biological nitrogen fixation (BNF) (Jensen et al., 2012). This capacity of fixation, ranges from 90 to $200 \mathrm{~kg} \mathrm{~N}$ ha $^{-1}$ (Herridge et al., 2008; Neugschwandtner et al., 2015), with a potential of up to $300 \mathrm{~kg} \mathrm{~N}^{-1}$ (Singh et al., 2013). The nitrogen fixation variations depend on the variety, agronomic practices, soil properties and mainly on the presence of compatible symbiotic rhizobacteria in the soil (Argaw and Mnalku, 2017). However, the $\mathrm{BNF}$ is an energy intensive process that requires large amount of phosphorus.

Phosphorus is one of the major plant nutrients limiting growth due to its role in improving the nodulation process and BNF, root and nodule development, plant growth and formation of phosphoglycolate needed in photosynthesis (Kubure et al., 2016). However, approximately $70 \%$ of cultivated soils suffer from P limitation (Hinsinger, 2001), making P nutrition a great priority for maintaining good plant production. Only $20 \%$ to $30 \%$ of applied phosphate is used and absorbed by the plants and the remaining is lost due to interaction with soil components and microorganisms or run-off from soils to lakes, rivers and seas (Kirkby and Johnston, 2008). Therefore, even if soils contain high amounts of phosphorus, it is largely unavailable to the plant owing to its high reactivity with soil components such as iron, aluminium and calcium which result in the formation of highly insoluble forms of phosphorus.

Faba bean plants also require relatively large amounts of water, especially to ensure maximum seed germination and in some cases low water availability could also be a stress to more mature plants. In general, water stress is defined as the reduction of available soil moisture and the increase of plant water loss by transpiration (Jaleel et al., 2009). Climate change has become a threat around the world, causing floods in some areas and water scarcity and drought in others. Morocco is one of the areas that has started to suffer from water limitation especially for rain-fed agro-systems. Moreover, studies of the effect of water stress on plant production reported that water deficit reduced yield by $50 \%$ to $82 \%$ depending on its severity (Wang et al., 2003; Zlatev and Lidon, 2012). According to Razmjoo et al. (2008), plant tolerance to abiotic stresses is complicated by the interaction between various stress factors and the difference in physiological, biochemical and molecular processes involved in plant growth and development. For this reason, the occurrence of water deficit and phosphorus deficiency together represents dual constraints for crop production. Meanwhile, various key changes and adaptation mechanisms related to the tolerance to water deficit or phosphorus limitation, were associated to the decrease of growth and regulation of water status parameters such as biomass, leaf area, stomatal conductance, relative water content (Alghamdi et al., 2015) and the ability of the plants to keep the balance of leaf water potential, the photosynthetic function and membrane stability (Waraich et al., 2011; Kabbadj et al., 2017; Mouradi et al., 2018).

Furthermore, according to Zhu (2002) abiotic stressors such as drought may also induce osmotic and oxidative stress in plants. As a response, plants adopt various mechanisms such as compatible solutes accumulation, antioxidant system induction and reactive oxygen species (ROS) scavenging systems. Compatible solutes are highly soluble compounds that are usually nontoxic at high cellular concentrations (Giri, 2011) and include organic osmolytes like pro- line and glycine betaine and inorganic osmolytes like $\mathrm{K}^{+}, \mathrm{Ca}^{2+}$ and $\mathrm{Na}^{+}$(Farissi et al., 2013; Bargaz et al., 2015; Kabbadj et al., 2017). With reference to the morpho-physiological adaptation of plants to the combined effect of water deficit and phosphorus limitation, it is documented that their combined effect reduces nutrient uptake, relative water content, leaf water potential and photosynthetic activity (Shubhra et al., 2004; Jemo et al., 2017). However, as most of faba bean metabolism alterations are related to the regulation associated to water status, their change under the combined effect of water deficit and phosphorus limitation will give an understanding of the role of phosphorus level combined with drought on morpho-physiological response of faba bean plants.

The individual effects of water deficit and phosphorus deficiency on Aguadulce, Alfia, Reina Mora and Luz D'Otono varieties as the commonly grown faba bean varieties in Morocco, have been widely studied (Kabbadj et al., 2017; Makoudi et al., 2018; Mouradi et al., 2018) but there is a lack of information on their combined effects on faba bean plants and also of the beneficial effect of sufficient phosphorus fertilization on this species under water deficit. Moreover, an increase in water deficit in the Mediterranean area, as forecast for the coming decades, could be accompanied by a decreased in $\mathrm{P}$ soil availability for faba bean. Thus, the identification of physiological and molecular traits that vary in response to the combination of the two stress events remains a challenge. The present research was undertaken to assess the growth and nutrient uptake, as well as physiological and biochemical responses of four faba bean varieties under combined water and phosphorus shortage. Therefore, the aims of this study are to: i) investigate the individual and concurrent effects of drought and P stresses on growth, water status, osmolyte accumulation, nutrient uptake and membrane stability in faba bean; ii) examine the basis of the crop tolerance against drought and $\mathrm{P}$ stresses; and iii) assess the performance of four different varieties under drought and/or P stresses. We hypothesize that P shortage makes water deficit more severe and this combination will affect the faba bean metabolism differently compared to a single stress.

\section{Materials and methods}

\section{Treatments and trial description}

The experiment was set up under greenhouse conditions at the Faculty of Sciences and Techniques of Marrakech, with an average day/night temperature of $25 / 20^{\circ} \mathrm{C}$, an approximate relative humidity of 50 to $80 \%$ and a $16 \mathrm{~h}$ photoperiod. Four faba bean varieties frequently grown in the Haouz area of Morocco and known for their high nodulation and their different levels of tolerance to water deficit (Kabbaj et al., 2017); Aguadulce (Ag) and Alfia (Al) Moroccan varieties, and Luz d'Otono (LO) and Reina Mora (RM), Spanish ones, were used. The faba bean seeds were surface disinfected by immersion in 5\% sodium hypochlorite for $5 \mathrm{~min}$, rinsed four times in sterile distilled water and germinated in sterilized sand for 7 days. Seedlings were transplanted into plastic pots measuring $20 \mathrm{~cm}$ deep and $22 \mathrm{~cm}$ in diameter filled with $1.5 \mathrm{~kg}$ of sterilized sand and peat mixture $(4: 1, \mathrm{v} / \mathrm{v})$. Two seedlings were transplanted per pot. The pot was considered as an experimental unit. Five replicates (ten plants) per treatment per variety were considered. Each transplanted seedling was inoculated with $5 \mathrm{ml}$ Rhizobium leguminosarum RhF41 that was isolated and identified from nodules of faba beans grown at the Haouz area, at a rate of $10^{8}$ colony forming unit $(\mathrm{CFU}) \mathrm{mL}^{-1}$. 
Plants were irrigated with distilled water and Hoagland nitrogen free solution $\left(100 \mu \mathrm{mol} \mathrm{L}^{-1} \mathrm{MgSO}_{4}, 750 \mu \mathrm{mol} \mathrm{L}^{-1} \mathrm{~K}_{2} \mathrm{SO}_{4}\right.$,

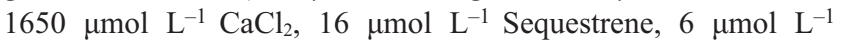
$\mathrm{MnSO}_{4}, 4 \mu \mathrm{mol} \mathrm{L}{ }^{-1} \mathrm{H}_{3} \mathrm{BO}_{3}, 1 \mu \mathrm{mol} \mathrm{L}{ }^{-1} \mathrm{ZnSO}_{4}, 0.1 \mu \mathrm{mol} \mathrm{L} \mathrm{L}^{-1}$ $\mathrm{NaMoO}_{4}, 1 \mu \mathrm{mol} \mathrm{L}{ }^{-1} \mathrm{CuSO}_{4}$ ); the nutrient solution was applied once a week with no additional nitrogen. Two weeks after transplantation, water was restricted to $40 \%$ field capacity (FC) for stressed plants versus $80 \%$ FC for non-stressed plants (controls) (Kabbadj et al., 2017) while phosphorus deficiency treatment consisted in the application of $25 \mu \mathrm{mol}$ of $\mathrm{P}$ plant ${ }^{-1}$ week $^{-1}$ versus 125 $\mu \mathrm{mol}$ of $\mathrm{P}$ plant $^{-1}$ week $^{-1}$ for sufficient $\mathrm{P}$ treatment, provided as $\mathrm{KH}_{2} \mathrm{PO}_{4}$ (Makoudi et al., 2018). The combined stress was applied by submitting the plants to water deficit $(40 \%$ FC) and P deficiency $\left(25 \mu \mathrm{mol}\right.$ of $\mathrm{P}$ plant $^{-1}$ week $\left.^{-1}\right)$. At the flowering stage; 50 to 55 days after sowing (61 BBCH-scale) and 40 days of stress, leaf water potential, stomatal conductance and photosynthetic performance were measured in situ on the plants under the greenhouse conditions while leaf samples and plants were collected for growth, physiological and biochemical assessment.

\section{Plant dry weight measurement}

At flowering stage, plants were harvested and shoots were separated from the roots using sharp scissors. Then, substrate attached to the root was carefully removed using a brush and washed several times using distilled water. Nodules were collected from each plant using metal tweezers. The three plant parts were dried in an oven (Binder ${ }^{\mathrm{TM}}$ series FD-S Solid.Line) at $70^{\circ} \mathrm{C}$ for $48 \mathrm{~h}$ and the dry weight was measured for ten plants per treatment per variety.

Three random samples were used for nitrogen, phosphorus, $\mathrm{Na}^{+}, \mathrm{K}^{+}$and $\mathrm{Ca}^{2+}$ concentration analyses for each treatment and per variety for the three plant parts, from the ten dried plants.

\section{Leaf area}

At the flowering stage, leaf samples were collected and their surfaces were measured using Image J Software (http://rsb.info. nih.gov/ij/index.html). Three replications per treatment per variety were used.

\section{Stomatal conductance}

The stomatal conductance is a response of ambient $\mathrm{CO}_{2}$ concentration, leaf air vapor pressure difference and leaf temperature and water status. It was measured on eight plants per treatment per variety, outliers were eliminated and the remaining values were regrouped to form three replications. The measures were taken at noon under $28 \pm 2^{\circ} \mathrm{C}$ and $58 \pm 4 \%$ of relative humidity on leaves with a porometer (SC1 Model, Decagon Devices, version 2012).

\section{Relative water content}

Relative water content (RWC) represents the water that a leaf contains relative to its water content at full turgidity. To measure this parameter, fresh weights (FW) of foliar disks of three leaves per treatment and per variety were determined. They were then immersed for $6 \mathrm{~h}$ in distilled water to reach full turgidity. After wiping the surface water from leaf disks, their turgid weights (TW) were measured. Then samples were dried for $24 \mathrm{~h}$ at $70^{\circ} \mathrm{C}$ and their dry weights (DW) were determined. The RWC was determined using the following formula (Ghoulam et al. 2002).

$$
\mathrm{RWC}=(\mathrm{FW}-\mathrm{DW}) \times 100
$$$$
(\mathrm{TW}-\mathrm{DW})
$$

\section{Chlorophyll fluorescence $\left(\mathbf{F}_{\mathrm{v}} / \mathbf{F}_{\mathrm{m}}\right)$}

At $61 \mathrm{BBCH}$-scale of growth stage, chlorophyll fluorescence which gives an estimation of the degree of photoinhibition (Jifon and Syvertsen, 2003) was measured with a fluorimeter (Handy PEA, Hansatech, England). The illumination of the leaves with a beam of saturating light after their dark adaptation for 20 to 30 min, permits the determination of $F_{m}, F_{0}$ and $F_{v}\left(F_{m}-F_{0}\right)$ which are respectively the maximal quantum yield of PS II, the minimal fluorescence intensity and the variable fluorescence. The chlorophyll fluorescence of six leaves per treatment per variety was quantified by $\mathrm{F}_{\mathrm{v}} / \mathrm{F}_{\mathrm{m}}$ ratio and grouped in three replicates.

\section{Leaf water potential}

Leaf water potential was measured at noon on six leaf samples belonging to the same foliar rank on stem, per treatment and per variety. Water potential was measured using a pressure chamber (PMS Instrument Co, Model 600, USA).

\section{Membrane permeability}

The membrane stability was determined by measuring the electrolyte leakage from leaf disks. Leaf samples were washed 3 times with deionized water and leaf disks were cut and shaken for $24 \mathrm{~h}$ in sealed vials containing $10 \mathrm{ml}$ of deionized water. Electrical conductivity of the solution (E1) was determined with a conductivity meter (Hannah Instruments $\mathrm{HI} 8820 \mathrm{~N}$ ) at $25^{\circ} \mathrm{C}$. The foliar disks were then autoclaved for $20 \mathrm{~min}$ at $120^{\circ} \mathrm{C}$ and the electrical conductivity was measured (E2) at $25^{\circ} \mathrm{C}$. The following formula was used to express the percentage of electrolyte leakage:

Electrolyte leakage $(\mathrm{EL})=\mathrm{E} 1 / \mathrm{E} 2 \times 100$

\section{Membrane lipids peroxidation}

Lipid peroxidation was assessed according to Šavicka and Skute (2010) by the estimation of malondialdehyde (MDA) accumulation. Leaf samples of $0.5 \mathrm{~g}$ were ground in $3 \mathrm{ml}$ of trichloroacetic acid (TCA) $0.1 \%(\mathrm{w} / \mathrm{v})$. Then, the homogenate was centrifuged at 14000 $\times \mathrm{g}$ for $15 \mathrm{~min}$ and $1 \mathrm{ml}$ of the obtained supernatant was mixed with $2.5 \mathrm{ml}$ thiobarbituric acid (TBA) $0.5 \%(\mathrm{w} / \mathrm{v})$ prepared in TCA $20 \%$ $(\mathrm{w} / \mathrm{v})$. After, incubation at $95^{\circ} \mathrm{C}$ for $30 \mathrm{~min}$ followed by immersion of the reaction tubes in an ice bath and centrifugation at $5000 \mathrm{rpm}$ for $5 \mathrm{~min}$, the absorption of the obtained supernatant was read at 532 $\mathrm{nm}$ and $600 \mathrm{~nm}$. The calculation of MDA accumulation of three replications per treatment were done based on the extinction coefficient $(\varepsilon)$ of $155 \mathrm{mM}^{-1} \mathrm{~cm}^{-1}$.

$\operatorname{MDA}(\mathrm{mM})=\underline{\mathrm{A} 532-\mathrm{A} 600}$

\section{Glycine betaine}

The accumulation of osmolytes like glycine betaine (GB) in cells is known to protect organisms against abiotic stresses via osmoregulation or osmoprotection. It was measured using $0.5 \mathrm{~g}$ of dried, ground leaves shaken in $20 \mathrm{~mL}$ of distilled water for $24 \mathrm{~h}$ at $25^{\circ} \mathrm{C}$. According to the method of Grieve and Grattan (1983), 0.5 $\mathrm{mL}$ of the extract was added to $0.5 \mathrm{~mL}$ of $\mathrm{H}_{2} \mathrm{SO}_{4}$ and was shaken in ice bath for $60 \mathrm{~min}$. A volume of $0.2 \mathrm{~mL}$ of Cold $\mathrm{KI}-\mathrm{I}_{2}$ reagent was added to $0.5 \mathrm{~mL}$ of the extract and then stored for $16 \mathrm{~h}$ at $4^{\circ} \mathrm{C}$ before centrifugation at $10,000 \mathrm{rpm}(8000 \times \mathrm{g})$ for $15 \mathrm{~min}$ at $4^{\circ} \mathrm{C}$. After elimination of the supernatant, the periodide crystals were dissolved in 9 $\mathrm{ml}$ of 1,2-dichloroethane and the absorbance was measured at 365 $\mathrm{nm}$ after 2 to $3 \mathrm{~h}$. The concentration was expressed as $\mu$ mol glycine betaine per $g$ of DW using calibration curves. Three replicates were 
performed per treatment and per variety.

\section{$\mathrm{P}, \mathrm{Na}^{+}, \mathrm{K}^{+}$and $\mathrm{Ca}^{2+}$ concentrations}

For the $\mathrm{P}, \mathrm{Na}^{+}, \mathrm{K}^{+}$and $\mathrm{Ca}^{2+}$ concentration measurements, dried samples of $0.5 \mathrm{~g}$ (shoot, root, and nodule) were incinerated at $600^{\circ} \mathrm{C}$ for $6 \mathrm{~h}$ in a Thermolyne Tabletop Muffle Furnaces. The ash formed was recovered by adding $3 \mathrm{ml}$ of $\mathrm{HCl}(10 \mathrm{~N})$. The solution was then filtered and adjusted to $100 \mathrm{~mL}$ by distilled water. The resulting solution was used for nutrient analyses (Ghoulam et al., 2002). For $P$ concentration determination, to $1 \mathrm{~mL}$ of the prepared solution, $4 \mathrm{ml}$ of distilled water and $5 \mathrm{ml}$ of a mixture of $2.5 \%$ $(\mathrm{w} / \mathrm{v})$ sodium molybdate and $0.15 \%(\mathrm{w} / \mathrm{v})$ hydrazine sulphate were added. The resulting solution was heated for $10 \mathrm{~min}$ in a $95^{\circ} \mathrm{C}$ water bath and after colour development the absorbance was measured by spectrometer at $820 \mathrm{~nm}$.

The $\mathrm{Na}^{+}, \mathrm{K}^{+}$and $\mathrm{Ca}^{2+}$ concentrations in the same prepared solution were determined by flame emission photometry (AFP100 Model, Biotech Management Engineering Co. Ltd., UK).

\section{Plant nitrogen concentrations}

Shoot and root nitrogen concentrations were determined according to Kjeldahl method. In matrass tubes, $10 \mathrm{~mL}$ of concentrated $\mathrm{H}_{2} \mathrm{SO}_{4}$ were added to $0.5 \mathrm{~g}$ dry biomass and $1 \mathrm{~g}$ catalyst and then digested for $2 \mathrm{~h}$ at $400^{\circ} \mathrm{C}$. A distillation unit connected to an Erlenmeyer flask containing a solution of $10 \mathrm{ml}$ of boric acid and $20 \mathrm{ml}$ of $\mathrm{NaOH}$ was used. The distillate was recovered and the total nitrogen concentration was determined by titration of $5 \mathrm{ml}$ of the distillate by sulfuric acid $\left(0.01 \mathrm{~mol} \mathrm{~L}^{-1}\right)$ using bromocresol green and methyl red as colour indicators. Three replicates were performed per treatment and per variety.

\section{Statistical analysis}

The experiment was set up using a split-split-plot design with the varieties [Aguadulce (Ag) and Alfia (Al), Luz d'Otono (LO) and Reina Mora (RM)] as the main plot, water regime (40\% FC, $80 \% \mathrm{FC})$ as the subplot, and P treatments (P0: 25 mol plant $^{-1}$ week $^{-1}, \mathrm{P} 1: 125$ $\mu$ mol plant ${ }^{-1}$ week $^{-1}$ ) as the sub-subplot. Each of the four main plots was blocked into five replicates. The data were statistically analysed using IBM SPSS statistics 20 software (IBM Corporation and Others, Armonk, NY, USA) and presented as the mean \pm standard error. The means were compared statistically at the level of $\mathrm{P}<0.05$ using Student-Newman-Keuls's multiple-range test (Tables 1-6).

\section{Results}

\section{Plant dry biomass}

The statistical analysis showed that water deficit and P deficiency either alone or combined, significantly affected $(\mathrm{P}<0.001$, Table 6) shoot, root dry weights. However, no significant difference was observed between the varieties' nodule dry weights in response to the combined water and $\mathrm{P}$ deficiency. Moreover, all varieties tested produced markedly higher biomass when water was not limiting, than under deficit conditions regardless of $\mathrm{P}$ level. But under the combined stress, the dry biomass reduction was more pronounced for almost all of plant tissues testes and in all of the tested faba bean varieties, compared to their corresponding controls (Figure 1).

Limiting P induced a slight decrease in shoot dry weight which was more pronounced under water deficit with a significant varia- tion observed for $\mathrm{Al}, \mathrm{LO}$ and $\mathrm{RM}$ varieties. Under the combined stressors, the variety RM presented the lowest biomass of $0.51 \mathrm{~g}$ plant $^{-1}$ versus $1.25 \mathrm{~g}_{\text {plant }}{ }^{-1}$ obtained by the Ag variety. The Ag presented the highest biomass and then a less reduction compared to its corresponding control. For root biomass, Ag variety showed the similar reductions under all treatments but produced the highest biomass (1.88 $\left.\mathrm{g} \mathrm{plant}^{-1}\right)$ when both stresses were combined, compared to $\mathrm{Al}$ variety which produced the lowest biomass $(0.87$ g plant $\left.{ }^{-1}\right)$. For nodule dry biomass, water deficit and its combina-

A

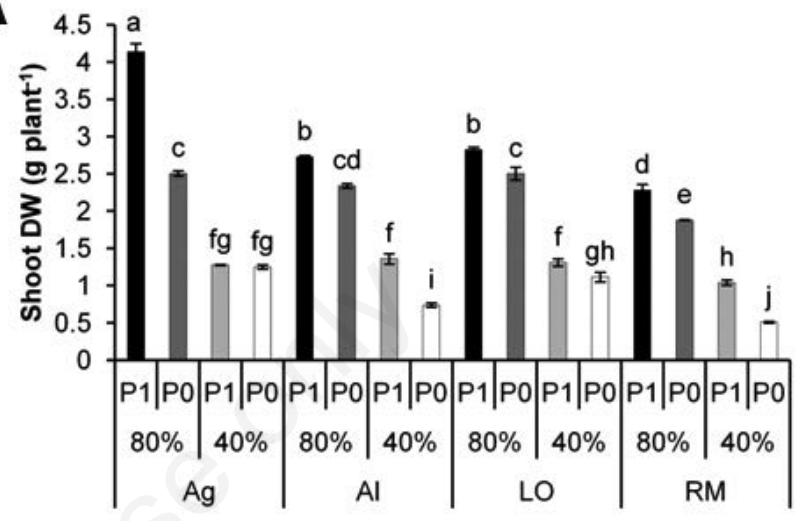

B

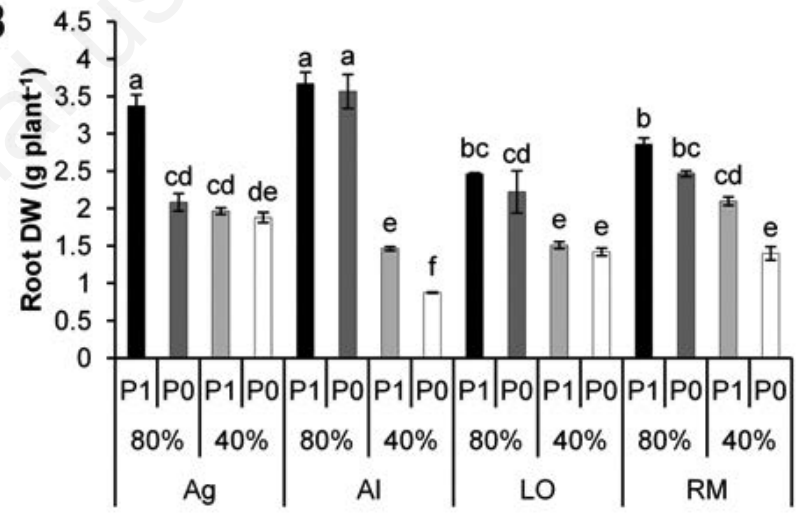

C

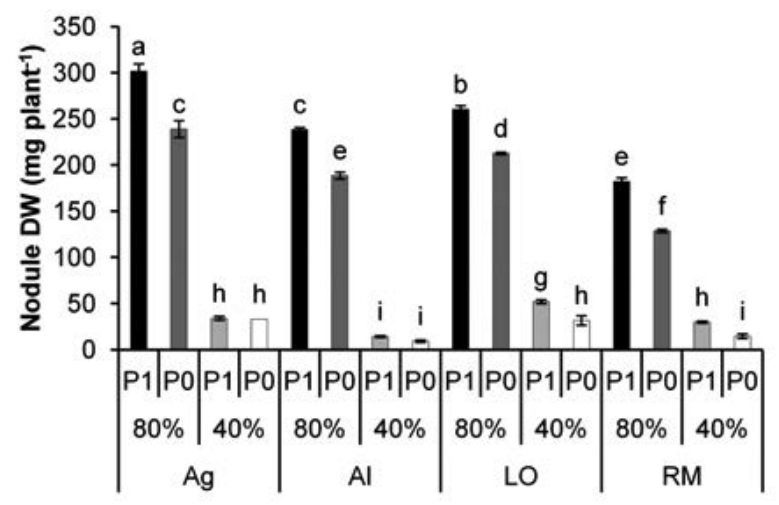

Figure 1. Plants dry biomass (A: Shoot, B: Root, C: Nodule) under water deficit $[40 \%$ field capacity $(\mathrm{FC})]$ and phosphorus deficiency $(25 \mu \mathrm{M})$ and their combination $(40 \% \mathrm{FC} ; 25 \mu \mathrm{M})$ in comparison to control condition $(80 \% \mathrm{FC}, 125 \mu \mathrm{M})$ of four faba bean varieties Ag (Aguadulce), Al (Alfia), LO (Luz de Otono) and RM (Reina Mora). The values represent the means of ten replications and the bars represent standard errors. Values with different letters are significantly different at $\mathbf{0 . 0 5}$ level of probability by Student-Newman-Keuls. 
tion with $\mathrm{P}$ limitation produced a severe reduction and it was more pronounced in $\mathrm{Al}$ and $\mathrm{RM}$ varieties, with a reduction rates relative to their corresponding controls of $96 \%$ and $92 \%$ respectively.

Under combined effect of water deficit and P deficiency, Ag presented the highest shoot, root and nodule dry weight $(1.25 ; 1.88$ g plant ${ }^{-1}$ and $33 \mathrm{mg} \mathrm{plant}^{-1}$ respectively for shoot, root and nodule).

\section{Leaf area}

Water stress, $\mathrm{P}$ deficiency and their interaction significantly reduced $(\mathrm{P}<0.001$, Table 6) leaf area and no significant difference was observed between the varieties in response to the combined stressors. Under all applied treatments, this parameter varied from 32 to $11 \mathrm{~cm}^{2}$ (Figure 2). For sufficient water regime and both $\mathrm{P}$

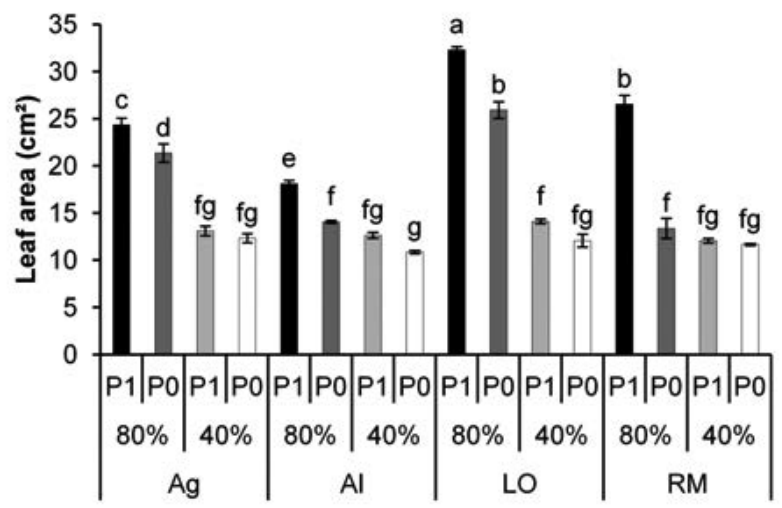

Figure 2. The effect of water deficit $[40 \%$ field capacity $(\mathrm{FC})]$ and phosphorus deficiency $(25 \mu \mathrm{M})$ and their combination (40\% FC; $25 \mu \mathrm{M})$ on four faba bean varieties' Leaf area. The values represent the means of three replications and the bars represent standard errors. Values with different letters are significantly different at 0.05 level of probability by Student-Newman-Keuls.

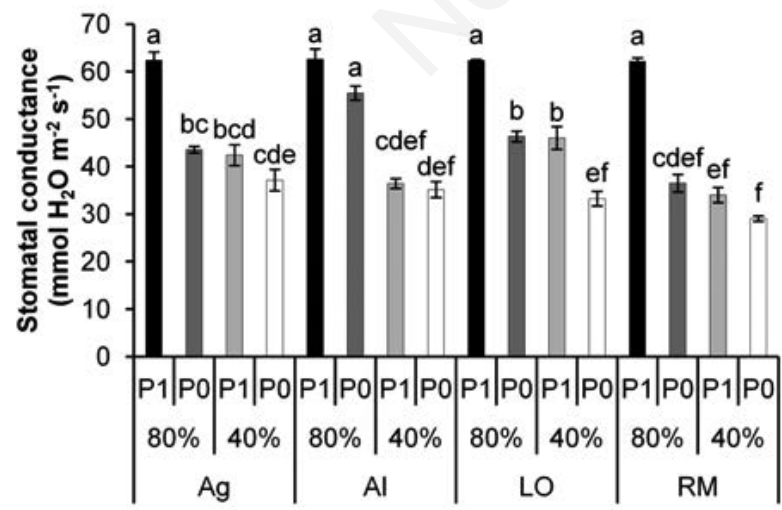

Figure 3. The effect of water deficit $[40 \%$ field capacity $(\mathrm{FC})]$ and phosphorus deficiency $(25 \mu \mathrm{M})$ and their combination (40\% FC; $25 \mu \mathrm{M})$ on stomatal conductance of faba bean varieties. The values represent the means of three replications and the bars represent standard errors. Values with different letters are significantly different at $\mathbf{0 . 0 5}$ level of probability by Student-Newman-Keuls. concentrations, the lowest leaf areas were obtained for Al variety and the highest ones for LO variety. However, LO variety showed the highest reduction rate of $62.6 \%$ under combined water and $\mathrm{P}$ deficiency relative to its control while $\mathrm{Al}$ variety showed the lowest reduction rate of $40 \%$.

\section{Stomatal conductance}

Under the studied abiotic stresses, water deficit, P limitation and their combination, stomatal conductance decreased significantly $(\mathrm{P}<0.05$, Table 6$)$. In general, this parameter similarly varied for all tested varieties. Under sufficient water and $\mathrm{P}$ concentrations, Ag exchanged $62 \mathrm{mmol} \mathrm{H}_{2} \mathrm{O} \mathrm{m}^{-2} \mathrm{~s}^{-1}$ (Figure 3). This conductance was reduced under combined water and $\mathrm{P}$ deficiency to $37 \mathrm{mmol}$ $\mathrm{H}_{2} \mathrm{O} \mathrm{m}^{-2} \mathrm{~s}^{-1}$, representing a decrease of $40 \%$. The highest decrease of stomatal conductance was noticed in the RM variety showing a reduction of $53 \%$ under the dual stress compared to its control. The $\mathrm{Al}$ and $\mathrm{LO}$ varieties showed a reduction of stomatal conductance of $44 \%$ and $47 \%$ respectively under combined stresses relative to their corresponding controls.

\section{Relative water content}

Statistical analysis revealed a significant effect of water deficit and $\mathrm{P}$ deficiency separately $(\mathrm{P}<0.001$, Table 6$)$ on the relative water content that leaves could hold in each variety. For control plants, RWC varied from $70 \%$ obtained in RM variety to $61.7 \%$ in LO variety. Under the combined stresses, RWC varied from $52 \%$, obtained in $\mathrm{Ag}$ variety to $43 \%$, obtained in $\mathrm{Al}$ variety. The RWC decreased the least in the $\mathrm{Ag}$ variety $(22 \%)$ and the RWC decreased the most in the RM variety $33 \%$ relative to their respective controls (Figure 4).

\section{Chlorophyll fluorescence $\left(\mathrm{F}_{\mathrm{v}} / \mathbf{F}_{\mathrm{m}}\right)$}

Results presented in Figure 5 show the responses of four faba bean varieties to water deficit and phosphorus deficiency and their

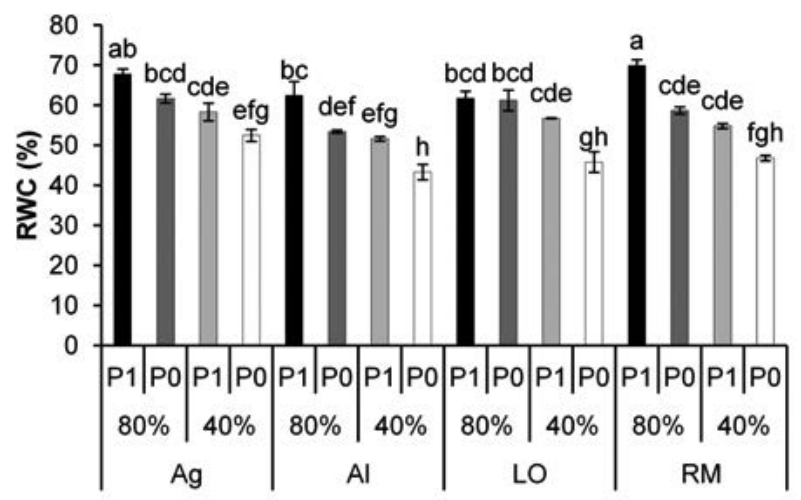

Figure 4. Relative water content (RWC) of 50 days old plants under water deficit $[40 \%$ field capacity (FC)] and phosphorus deficiency $(25 \mu \mathrm{M})$ and their combination $(40 \% \mathrm{FC} ; 25 \mu \mathrm{M})$ in comparison to control conditions $(80 \% \mathrm{FC} ; 125 \mu \mathrm{M})$ of four faba bean varieties Ag (Aguadulce), Al (Alfia), LO (Luz de Otono) and RM (Reina Mora). The values represent the means of three replications and the bars represent standard errors. Values with different letters are significantly different at 0.05 level of probability by Student-Newman-Keuls. 
combination regarding PS II activity. Under $80 \%$ FC, the maximum quantum yield of PS II varied from 0.833 observed in the variety $\mathrm{RM}$ to 0.807 in the $\mathrm{LO}$ variety. Under water deficit, this parameter varied from 0.796 to 0.711 in the $\mathrm{Al}$ variety in the presence of sufficient $\mathrm{P}$ treatment and $\mathrm{P}$ deficiency respectively. Therefore, limiting water had a greater effect on efficiency of photosystem II but the effect is decreased with sufficient P. Al variety showed the lowest $F_{v} / F_{m}$ value (0.711) under combined stresses and also the greatest reduction rate (14\%) relative to its control. Ag variety showed the highest $F_{v} / F_{m}$ value $(0.765)$ under combined stresses and also the lowest reduction $(7.6 \%)$ relative to its control. For statistical analysis, water deficit and phosphorus limitation had a significant individual effect $(\mathrm{P}<0.001$, Table 6) or combined $(\mathrm{P}<0.05)$.

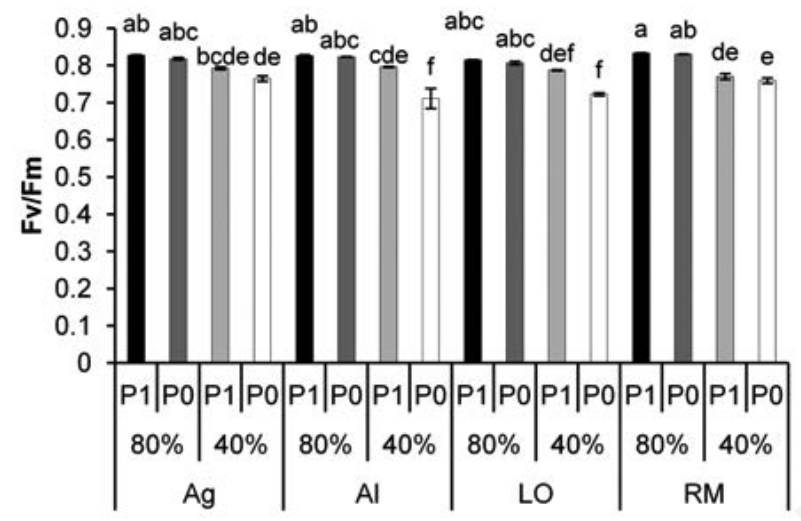

Figure 5. Efficiency of photosystem II $\left(\mathrm{F}_{\mathrm{v}} / \mathrm{F}_{\mathrm{m}}\right)$ under combined water deficit and phosphorus deficiency ( $40 \%$ field capacity; 25 $\mu M)$. The values represent the means of three replications and the bars represent standard errors. Values with different letters are significantly different at 0.05 level of probability by StudentNewman-Keuls.

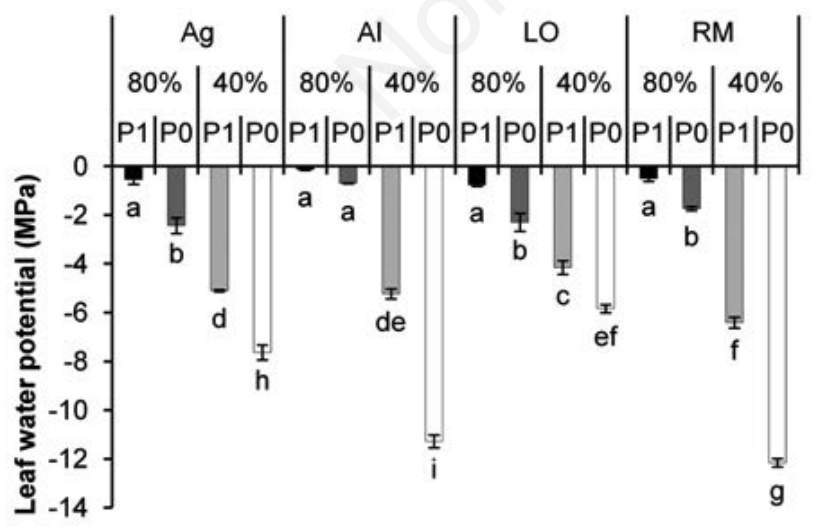

Figure 6. Variation of leaf water potential under water deficit (40\% field capacity), phosphorus limitation $(25 \mu \mathrm{M})$ and their combination in four faba bean varieties grown in greenhouse. The values represent the means of three replications and the bars represent standard errors. Values with different letters are significantly different at 0.05 level of probability by Student-NewmanKeuls.

\section{Leaf water potential}

The treatments of water stress and/or P deficiency reduced free water in leaves which means the need of high pressure to extract it. Our results showed a significant $(\mathrm{P}<0.001$, Table 6) decrease of leaf water potential under all treatments and it was most pronounced under the combined deficit. All the four varieties were affected by the stresses to a varying extent. LO variety was the least affected with $87 \%$ of water potential decrease under the combined water and $\mathrm{P}$ limitation, versus $98 \%$ for $\mathrm{Al}$ variety relative to their corresponding controls. Under water and P limiting conditions, the leaf water potential of varieties $\mathrm{LO}$ and $\mathrm{Ag}$ were -5.84 and $-7.64 \mathrm{MPa}$ respectively (Figure 6) in contrast to RM that showed the lowest leaf water potential with $-12.16 \mathrm{MPa}$.

\section{Membrane stability}

Electrolyte leakage and MDA have been studied in order to have more data on membrane stability. The statistical analysis of these two parameters revealed a significant effect of water deficit and $\mathrm{P}$ limitation when separated $(\mathrm{P}<0.001$, Table 6$)$ but no significant difference on MDA was observed with the combined treatment. Electrolyte leakage and MDA of the four varieties changed in a similar pattern after plant exposure to stresses (Figure 7).
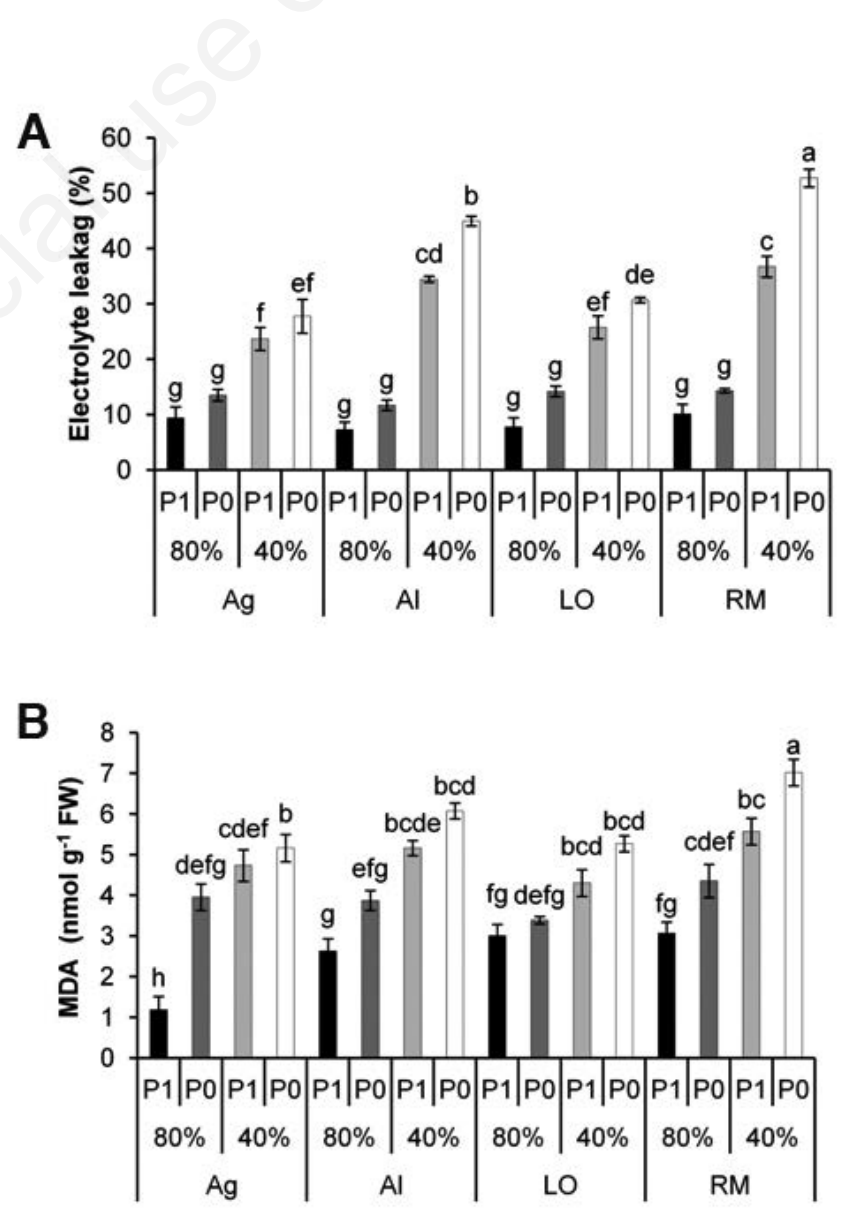

Figure 7. Electrolyte leakage (A) and malondialdehyde (B) accumulation as affected by water deficit, phosphorus deficiency and their combination in four faba bean varieties. The values represent the means of three replications and the bars represent standard errors. Values with different letters are significantly different at $\mathbf{0 . 0 5}$ level of probability by Student-Newman-Keuls. 
Water deficit induced an increase of these two parameters and the combination of both stresses caused greater increase in all of the tested varieties. Under water deficit combined with $\mathrm{P}$ deficiency the highest values of electrolyte leakage and MDA with 52.7\% and $7 \mathrm{nmol} \mathrm{g}{ }^{-1} \mathrm{FW}$ respectively, were obtained in RM variety. On the other hand, Ag variety presented the lowest electrolyte leakage value and MDA accumulation consisting of $27.8 \%$ and $5.16 \mathrm{nmol}$ $\mathrm{g}^{-1} \mathrm{FW}$ respectively. These low values for $\mathrm{Ag}$ variety were significantly different from $\mathrm{Al}$ and $\mathrm{RM}$ varieties for electrolyte leakage but only from RM for MDA.

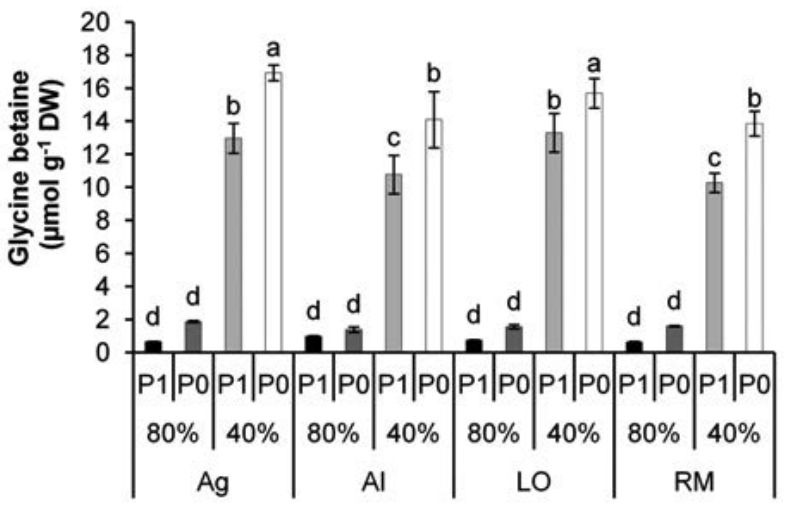

Figure 8. Glycine betaine accumulation under water deficit $[40 \%$ field capacity (FC)], phosphorus deficiency $(25 \mu \mathrm{M})$ and their combination ( $40 \% \mathrm{FC} ; 25 \mu \mathrm{M})$ in four faba bean varieties; $\mathrm{Ag}$ (Aguadulce), Al (Alfia), LO (Luz de Otono) and RM (Reina Mora). The values represent the means of three replications and the bars represent standard errors. Values with different letters are significantly different at $\mathbf{0 . 0 5}$ level of probability by StudentNewman-Keuls.

\section{Glycine betaine}

The results presented in Figure 8 show the accumulation of glycine betaine $(\mathrm{GB})$ in the four faba bean varieties. They revealed a high increase of glycine betaine accumulation under water deficit irrespective of $\mathrm{P}$ level. Therefore, GB accumulation responded more strongly to water deficit than to P deficiency. Nevertheless, the highest accumulation was obtained under water deficit combined with $\mathrm{P}$ shortage for all of the tested varieties and was reduced in the presence of phosphorus. Indeed, statistical analysis showed: i) a significant difference between the varieties $(\mathrm{P}<0.001$, Table 6$)$ in response to water deficit for GB accumulation; ii) no significant differences were observed between the varieties in response to $\mathrm{P}$ limitation under adequate moisture; and so, iii) water deficit has a more marked effect than P deficiency. Our results showed that Ag and LO varieties accumulated the highest amounts of GB (16.92 and 15.69 $\mu \mathrm{mol} \mathrm{g} \mathrm{g}^{-1} \mathrm{DW}$ respectively) while $\mathrm{RM}$ and $\mathrm{Al}$ varieties accumulated the lowest amounts (13.85 and $14.09 \mu \mathrm{mol} \mathrm{g}^{-1}$ DW respectively) under the combination of both constraints. The presence of sufficient phosphorus under water deficit induced much reduced quantities of GB; $12.97 \mu \mathrm{mol} \mathrm{g}{ }^{-1} \mathrm{DW}$ and $10.27 \mu \mathrm{mol} \mathrm{g}^{-1} \mathrm{DW}$ respectively for $\mathrm{Ag}$ and RM.

\section{Plant nutrients concentrations}

The statistical analysis revealed a significant $(\mathrm{P}<0.001$, Table 6) effect of water deficit and P deficiency on shoot, root and nodule $\mathrm{P}$ concentrations while no significant difference was observed under the combined water deficit and phosphorus deficiency on root $\mathrm{P}$ concentration between varieties. Limiting $\mathrm{P}$ had a greater effect on $\mathrm{P}$ concentration regardless of water regime.

LO variety showed the highest $P$ concentration in all of the plant parts tested for the control treatment $\left(0.44,0.28\right.$ and $0.52 \mathrm{mg} \mathrm{g}^{-1} \mathrm{DW}$ respectively for shoot, root and nodule, Table 1$)$. Ag variety P concentration showed a significant similarity to that of LO variety in the shoot. Under water deficit and P deficiency, P concentration in shoot decreased the least in the $\mathrm{Ag}$ variety $(33.36 \%)$ and decreased the

Table 1. Shoot, root and nodule phosphorus concentrations under different phosphorus (P) treatments (P1; $125 \mu \mathrm{M}$ versus $\mathrm{P0} ; 25 \mu \mathrm{M})$, irrigation treatments $[80 \%$ field capacity (FC) versus $40 \% \mathrm{FC}]$ and their combination $(25 \mu \mathrm{M}, 40 \% \mathrm{FC})$ in four faba bean varieties grown in greenhouse conditions.

\begin{tabular}{|c|c|c|c|c|c|}
\hline Varieties & Irrigation treatment & Phosphorus treatment & $\begin{array}{l}\text { P-Shoot } \\
\mathrm{mg} \mathrm{g}^{-1} \mathrm{DW}\end{array}$ & $\begin{array}{l}\text { P-Root } \\
\mathrm{mg} \mathrm{g}^{-1} \mathrm{DW}\end{array}$ & $\begin{array}{l}\text { P-Nodule } \\
\mathrm{mg} \mathrm{g}^{-1} \mathrm{DW}\end{array}$ \\
\hline $\mathrm{Ag}$ & $80 \%$ & P1 & $0.41 \pm 0.04^{\mathrm{ab}}$ & $0.26 \pm 0.012^{b}$ & $0.41 \pm 0.018^{b}$ \\
\hline $\mathrm{Ag}$ & $80 \%$ & $\mathrm{PO}$ & $0.31 \pm 0.01 \mathrm{de}$ & $0.17 \pm 0.004^{\mathrm{fg}}$ & $0.28 \pm 0.029 \mathrm{def}$ \\
\hline $\mathrm{Ag}$ & $40 \%$ & P1 & $0.34 \pm 0.01^{\mathrm{cd}}$ & $0.21 \pm 0.012^{\mathrm{cd}}$ & $0.38 \pm 0.005^{b}$ \\
\hline $\mathrm{Ag}$ & $40 \%$ & $\mathrm{PO}$ & $0.27 \pm 0.01^{\mathrm{ef}}$ & $0.14 \pm 0.002^{\mathrm{h}}$ & $0.23 \pm 0.022^{g}$ \\
\hline $\mathrm{Al}$ & $80 \%$ & P1 & $0.37 \pm 0.04^{\mathrm{bc}}$ & $0.21 \pm 0.010^{\mathrm{cd}}$ & $0.34 \pm 0.031^{c}$ \\
\hline $\mathrm{Al}$ & $80 \%$ & $\mathrm{PO}$ & $0.30 \pm 0.02^{\mathrm{de}}$ & $0.17 \pm 0.004^{\mathrm{ef}}$ & $0.26 \pm 0.029^{\mathrm{efg}}$ \\
\hline $\mathrm{Al}$ & $40 \%$ & P1 & $0.32 \pm 0.01^{\text {cde }}$ & $0.19 \pm 0.006^{\text {def }}$ & $0.34 \pm 0.046^{b}$ \\
\hline $\mathrm{Al}$ & $40 \%$ & $\mathrm{PO}$ & $0.21 \pm 0.02^{\mathrm{fg}}$ & $0.14 \pm 0.021^{\mathrm{h}}$ & $0.14 \pm 0.018 \mathrm{i}$ \\
\hline LO & $80 \%$ & P1 & $0.44 \pm 0.04^{\mathrm{a}}$ & $0.28 \pm 0.024^{\mathrm{a}}$ & $0.52 \pm 0.013^{\mathrm{a}}$ \\
\hline LO & $80 \%$ & $\mathrm{PO}$ & $0.26 \pm 0.02^{\mathrm{ef}}$ & $0.20 \pm 0.004^{\mathrm{de}}$ & $0.25 \pm 0.013^{\mathrm{fg}}$ \\
\hline LO & $40 \%$ & P1 & $0.28 \pm 0.03^{\mathrm{ef}}$ & $0.23 \pm 0.003^{c}$ & $0.29 \pm 0.025^{\mathrm{de}}$ \\
\hline LO & $40 \%$ & $\mathrm{PO}$ & $0.26 \pm 0.06^{\mathrm{ef}}$ & $0.14 \pm 0.009^{h}$ & $0.09 \pm 0.017^{\mathrm{j}}$ \\
\hline RM & $80 \%$ & P1 & $0.32 \pm 0.04^{\text {cde }}$ & $0.18 \pm 0.027 \mathrm{def}$ & $0.31 \pm 0.002^{\mathrm{d}}$ \\
\hline RM & $80 \%$ & $\mathrm{PO}$ & $0.22 \pm 0.02^{\mathrm{fg}}$ & $0.15 \pm 0.004^{\mathrm{gh}}$ & $0.19 \pm 0.013^{\mathrm{h}}$ \\
\hline RM & $40 \%$ & P1 & $0.26 \pm 0.04^{\mathrm{ef}}$ & $0.18 \pm 0.013^{\text {ef }}$ & $0.28 \pm 0.007^{\mathrm{def}}$ \\
\hline RM & $40 \%$ & $\mathrm{PO}$ & $0.19 \pm 0.03^{g}$ & $0.13 \pm 0.005^{\mathrm{h}}$ & $0.10 \pm 0.007^{j}$ \\
\hline
\end{tabular}

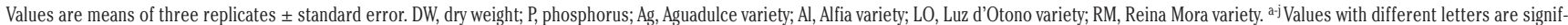
icantly different at 0.05 level of probability by Student-Newman-Keuls. 
most in $\mathrm{Al}$ variety $(42.62 \%)$ relative to their respective controls. For the nodules, $\mathrm{Ag}$ variety had the highest $\mathrm{P}$ concentration $\left(0.23 \mathrm{mg} \mathrm{g}^{-1}\right.$ DW) while LO and RM varieties showed the lowest ones with 0.09 and $0.10 \mathrm{mg} \mathrm{g}^{-1} \mathrm{DW}$ respectively. The statistical analysis revealed a significant individual effect of water deficit and $\mathrm{P}$ deficiency on shoot, root and nodule $\mathrm{K}^{+}, \mathrm{Na}^{+}$and $\mathrm{Ca}^{2+}$ concentrations $(\mathrm{P}<0.001$, Table 6). However, the combined effect of water deficit and $\mathrm{P}$ deficiency on the four varieties was statistically insignificant on $\mathrm{Ca}^{2+}$ concentration in shoot and $\mathrm{K}^{+}$concentration in root. For all varieties (Ag, Al, LO and RM) the leaf $\mathrm{K}^{+}$ions accumulated more than $\mathrm{Na}^{+}$ and $\mathrm{Ca}^{2+}$ in the controls and in the stressed plants (Table 2) while nodules accumulated $\mathrm{Ca}^{2+}$ in the highest concentrations for all treatments and varieties (Table 4). $\mathrm{Na}^{+}$ions accumulated more in roots under both stresses (Table 3). Under the combined effect of water deficit and phosphorus limitation, Ag variety accumulated significantly more $\mathrm{Ca}^{2+}$ in its shoots, roots and nodules (18.75, 28.38, $39.93 \mathrm{mg} \mathrm{g}^{-1} \mathrm{DW}$ respectively), and $\mathrm{Na}^{+}$in its nodules $\left(24 \mathrm{mg} \mathrm{g}^{-1}\right.$ DW, Table 4). The lowest concentrations of $\mathrm{Na}^{+}$and $\mathrm{Ca}^{2+}$ were observed in RM variety respectively in nodules (14.54 $\left.\mathrm{mg} \mathrm{g}^{-1} \mathrm{DW}\right)$ and shoots $\left(9.29 \mathrm{mg} \mathrm{g}^{-1} \mathrm{DW}\right.$, Table 2$)$ while Al variety had the low-

Table 2. Shoot $\mathrm{K}^{+}, \mathrm{Na}^{+}$and $\mathrm{Ca}^{2+}$ concentrations of faba bean varieties under different phosphorus (P) treatments (P1; $125 \mu \mathrm{M}$ and P0; $25 \mu \mathrm{M})$ and irrigation treatments $[80 \%$ field capacity (FC) versus $40 \% \mathrm{FC}]$.

\begin{tabular}{|c|c|c|c|c|c|}
\hline Varieties & Irrigation treatment & Phosphorus treatment & $\begin{array}{c}\mathrm{K}^{+} \\
\mathrm{mg} \mathrm{\textrm {g } ^ { - 1 }} \mathrm{DW}\end{array}$ & $\begin{array}{c}\mathrm{Na}^{+} \\
\mathrm{mg} \mathrm{g}^{-1} \mathrm{DW}\end{array}$ & $\begin{array}{c}\mathrm{Ca}^{2+} \\
\mathrm{mg} \mathrm{g}^{-1} \mathrm{DW}\end{array}$ \\
\hline $\mathrm{Ag}$ & $80 \%$ & P1 & $17.19 \pm 0.69^{c}$ & $4.78 \pm 0.29 \mathrm{de}$ & $8.51 \pm 0.73^{\mathrm{e}}$ \\
\hline $\mathrm{Ag}$ & $80 \%$ & $\mathrm{P} 0$ & $17.97 \pm 0.65^{\mathrm{c}}$ & $6.18 \pm 0.30^{\mathrm{abc}}$ & $11.49 \pm 0.60^{\mathrm{d}}$ \\
\hline $\mathrm{Ag}$ & $40 \%$ & $\mathrm{P} 1$ & $21.81 \pm 0.59^{\mathrm{ab}}$ & $7.22 \pm 0.24^{\mathrm{a}}$ & $15.48 \pm 0.47^{\mathrm{bc}}$ \\
\hline $\mathrm{Ag}$ & $40 \%$ & $\mathrm{P} 0$ & $23.22 \pm 0.28^{\mathrm{a}}$ & $7.26 \pm 0.54^{\mathrm{a}}$ & $18.75 \pm 0.59^{\mathrm{a}}$ \\
\hline $\mathrm{Al}$ & $80 \%$ & P1 & $15.92 \pm 1.28^{\mathrm{cd}}$ & $4.35 \pm 0.21^{\mathrm{de}}$ & $9.12 \pm 0.72^{\mathrm{e}}$ \\
\hline $\mathrm{Al}$ & $80 \%$ & $\mathrm{P} 0$ & $20.3 \pm 0.28^{b}$ & $5.23 \pm 0.65^{\text {cde }}$ & $9.62 \pm 0.88^{\mathrm{e}}$ \\
\hline $\mathrm{Al}$ & $40 \%$ & P1 & $19.9 \pm 1.08^{b}$ & $6.75 \pm 0.85^{\mathrm{ab}}$ & $11.75 \pm 0.82^{\mathrm{d}}$ \\
\hline $\mathrm{Al}$ & $40 \%$ & $\mathrm{P} 0$ & $21.61 \pm 0.35^{\mathrm{ab}}$ & $7.21 \pm 0.65^{\mathrm{a}}$ & $12.85 \pm 0.66^{\mathrm{cd}}$ \\
\hline $\mathrm{LO}$ & $80 \%$ & P1 & $17.01 \pm 1.97^{\mathrm{c}}$ & $4.77 \pm 0.33^{\mathrm{de}}$ & $8.69 \pm 0.52^{\mathrm{e}}$ \\
\hline LO & $80 \%$ & $\mathrm{P} 0$ & $16.07 \pm 0.57^{\mathrm{cd}}$ & $6.52 \pm 0.22^{\mathrm{ab}}$ & $11.72 \pm 1.26^{\mathrm{d}}$ \\
\hline LO & $40 \%$ & $\mathrm{P} 1$ & $20.6 \pm 0.52^{\mathrm{b}}$ & $6.55 \pm 0.09^{\mathrm{ab}}$ & $14.31 \pm 0.95^{b c}$ \\
\hline LO & $40 \%$ & $\mathrm{PO}$ & $21.14 \pm 0.42^{b}$ & $7.08 \pm 0.96^{\mathrm{a}}$ & $14.27 \pm 1.07^{\mathrm{b}}$ \\
\hline RM & $80 \%$ & P1 & $14.6 \pm 1.72^{\mathrm{d}}$ & $3.93 \pm 0.31^{\mathrm{e}}$ & $7.47 \pm 0.53^{\mathrm{e}}$ \\
\hline RM & $80 \%$ & P0 & $17.47 \pm 0.69^{c}$ & $4.09 \pm 0.55^{\mathrm{e}}$ & $8.14 \pm 0.66^{\mathrm{e}}$ \\
\hline RM & $40 \%$ & $a_{n}$ & $19.81 \pm 0.33^{b}$ & $4.95 \pm 0.37 \mathrm{de}$ & $8.42 \pm 0.52^{\mathrm{e}}$ \\
\hline RM & $40 \%$ & $\mathrm{P} 0$ & $21.18 \pm 0.5^{b}$ & $5.69 \pm 0.33^{\mathrm{bcd}}$ & $9.29 \pm 1.06^{\mathrm{e}}$ \\
\hline
\end{tabular}

Values are means of three replicates \pm standard error. DW, dry weight; P, phosphorus; Ag, Aguadulce variety; Al, Alfia variety; LO, Luz d'Otono variety; RM, Reina Mora variety. ${ }^{\text {ae }}{ }^{-}$alues with different letters are significantly different at 0.05 level of probability by Student-Newman-Keuls.

Table 3. Root $\mathrm{K}^{+}, \mathrm{Na}^{+}$and $\mathrm{Ca}^{2+}$ concentrations of faba bean varieties under different phosphorus (P) treatments (P1; 125 $\mu \mathrm{M}$ and P0; $25 \mu \mathrm{M}$ ) and irrigation treatments [80\% field capacity (FC) versus $40 \% \mathrm{FC}$ ].

\begin{tabular}{|c|c|c|c|c|c|}
\hline \multirow[t]{2}{*}{ Varieties } & \multirow[t]{2}{*}{ Irrigation treatment } & \multirow[t]{2}{*}{ Phosphorus treatment } & \multicolumn{3}{|c|}{ Root nutrient concentration } \\
\hline & & & $\begin{array}{c}\mathrm{K}^{+} \\
\mathrm{mg} \mathrm{g}^{-1} \mathrm{DW}\end{array}$ & $\begin{array}{c}\mathrm{Na}^{+} \\
\mathrm{mg} \mathrm{g} \mathrm{g}^{-1} \mathrm{DW}\end{array}$ & $\begin{array}{c}\mathrm{Ca}^{2+} \\
\mathrm{mg} \mathrm{g}^{-1} \mathrm{DW}\end{array}$ \\
\hline $\mathrm{Ag}$ & $80 \%$ & P1 & $7.31 \pm 0.77^{\mathrm{h}}$ & $11.83 \pm 0.53^{\mathrm{f}}$ & $10.8 \pm 1.07^{\mathrm{gh}}$ \\
\hline $\mathrm{Ag}$ & $80 \%$ & $\mathrm{P} 0$ & $8.72 \pm 0.56^{\mathrm{fg}}$ & $14.89 \pm 0.47^{\mathrm{d}}$ & $15.42 \pm 1.70^{\mathrm{d}}$ \\
\hline $\mathrm{Ag}$ & $40 \%$ & P1 & $10.23 \pm 0.67^{\text {bcde }}$ & $17.45 \pm 0.17^{\mathrm{a}}$ & $21.49 \pm 1.57^{\mathrm{b}}$ \\
\hline $\mathrm{Ag}$ & $40 \%$ & P0 & $12.44 \pm 0.24^{\mathrm{a}}$ & $17.6 \pm 0.42^{\mathrm{a}}$ & $28.38 \pm 0.76^{\mathrm{a}}$ \\
\hline $\mathrm{Al}$ & $80 \%$ & P1 & $8.99 \pm 0.57^{\mathrm{efg}}$ & $15.78 \pm 0.26^{\mathrm{bcd}}$ & $8.51 \pm 0.62^{\mathrm{i}}$ \\
\hline $\mathrm{Al}$ & $80 \%$ & $\mathrm{P} 0$ & $9.75 \pm 0.45^{\mathrm{def}}$ & $16.71 \pm 0.65^{\mathrm{ab}}$ & $11.56 \pm 0.44^{\mathrm{fg}}$ \\
\hline $\mathrm{Al}$ & $40 \%$ & $\mathrm{P} 1$ & $11.64 \pm 0.98 \mathrm{ab}$ & $15.74 \pm 0.04^{\text {bcd }}$ & $12.23 \pm 0.21^{\text {efg }}$ \\
\hline $\mathrm{Al}$ & $40 \%$ & $\mathrm{PO}$ & $11.24 \pm 0.8^{\mathrm{abc}}$ & $17.6 \pm 0.36^{\mathrm{a}}$ & $14.28 \pm 0.82^{\mathrm{de}}$ \\
\hline LO & $80 \%$ & P1 & $8.38 \pm 0.66^{\mathrm{g}}$ & $10.57 \pm 0.50^{g}$ & $10.4 \pm 0.86^{\text {ghi }}$ \\
\hline LO & $80 \%$ & $\mathrm{P} 0$ & $11.13 \pm 0.55$ abc & $14.84 \pm 0.1^{\mathrm{d}}$ & $11.45 \pm 0.32^{\mathrm{fg}}$ \\
\hline $\mathrm{LO}$ & $40 \%$ & P1 & $11.61 \pm 0.41^{\mathrm{ab}}$ & $16.08 \pm 0.66^{\mathrm{d}}$ & $13.66 \pm 0.38^{\mathrm{def}}$ \\
\hline LO & $40 \%$ & P0 & $12.19 \pm 0.93^{\mathrm{a}}$ & $17.6 \pm 0.36^{\mathrm{bc}}$ & $20.44 \pm 0.88^{b}$ \\
\hline $\mathrm{RM}$ & $80 \%$ & P1 & $8.9 \pm 0.4^{\text {efg }}$ & $13.25 \pm 0.73^{\mathrm{e}}$ & $8.99 \pm 0.70^{\text {hi }}$ \\
\hline RM & $80 \%$ & $\mathrm{PO}$ & $9.89 \pm 0.89^{\text {cdef }}$ & $14.68 \pm 0.56^{\mathrm{d}}$ & $13.64 \pm 0.46^{\mathrm{def}}$ \\
\hline RM & $40 \%$ & P1 & $10.95 \pm 0.56^{\mathrm{abcd}}$ & $15.43 \pm 0.07^{\mathrm{cd}}$ & $18.5 \pm 0.32^{c}$ \\
\hline RM & $40 \%$ & $\mathrm{PO}$ & $11.96 \pm 0.28^{a}$ & $16.1 \pm 0.48^{\mathrm{bc}}$ & $20.49 \pm 0.87^{b}$ \\
\hline
\end{tabular}

Values are means of three replicates \pm standard error. DW, dry weight; P, phosphorus; Ag, Aguadulce variety; Al, Alfia variety; LO, Luz d'Otono variety; RM, Reina Mora variety. a-iValues with different letters are significantly different at 0.05 level of probability by Student-Newman-Keuls. 
est concentration of $\mathrm{Ca}^{2+}$ in roots $\left(14.18 \mathrm{mg} \mathrm{g}^{-1} \mathrm{DW}\right.$, Table 3$)$ and nodules (26.63 $\left.\mathrm{mg} \mathrm{g}^{-1} \mathrm{DW}\right)$. Under sufficient water and phosphorus nutrition, the significant variations between the varieties were observed in $\mathrm{Na}^{+}$concentration in roots and nodules. In roots, the highest concentration was observed in $\mathrm{Al}$ variety $\left(15.78 \mathrm{mg} \mathrm{g}^{-1} \mathrm{DW}\right)$ and the lowest one was observed in LO variety $\left(10.57 \mathrm{mg} \mathrm{g}^{-1} \mathrm{DW}\right)$. $\mathrm{LO}$ variety produced the highest concentration in nodules $(7.92 \mathrm{mg}$ $\left.\mathrm{g}^{-1} \mathrm{DW}\right)$ while $\mathrm{RM}$ variety had the lowest $\mathrm{Na}^{+}$concentration (3.16 $\left.\mathrm{mg} \mathrm{g}^{-1} \mathrm{DW}\right)$.

\section{Plant nitrogen concentration}

$\mathrm{Ag}$ variety had the significantly highest concentration in shoot (4.65\%, Figure 9A) under sufficient water and P treatment. For water deficit and phosphorus deficiency, they had a significant individual effect $(\mathrm{P}<0.001$, Table 6$)$ on shoot and root $\mathrm{N}$ concentration. As Figure 9 shows, the combined effect of water deficit and $\mathrm{P}$ deficiency relative to the control, produced a significant reduction rate of $20 \%$ of $\mathrm{N}$ concentration in shoot of $\mathrm{Ag}$ variety and of $29.8 \%, 26.5$ and $30 \%$ respectively in $\mathrm{Al}, \mathrm{LO}$ and $\mathrm{RM}$ root $\mathrm{N}$ concentrations.

\section{Correlation}

All parameters studied were correlated significantly $(\mathrm{P}<0.01$, Table 5). Shoots represent the most important part of the plant for ensuring a good yield, because of their role as a source for nutrients and their translocation to the seeds. Nodules are also important because they ensure nitrogen fixation resulting from symbiosis with nitrogen fixing rhizobia. For these reasons we focused on shoot and nodule correlation to all the studied parameters. Shoot dry weight was more positively correlated to nodule dry weight $(\mathrm{r}=0.951)$, stomatal conductance $(\mathrm{r}=0.824)$, shoot and root nitrogen concentrations $(\mathrm{r}=0.623 ; \mathrm{r}=0.638)$ and negatively correlated to electrolyte leakage $(\mathrm{r}=-0.848)$, MDA $(\mathrm{r}=-0.891)$, glycine betaine $(\mathrm{r}=-0.839)$. While, nodule dry weight was positively correlated to leaf area $(\mathrm{r}=0.819)$, leaf water potential $(\mathrm{r}=0.808)$, stomatal conductance $(\mathrm{r}=0.819)$ and relative to root $\mathrm{N}$ concentration $(\mathrm{r}=0.523)$

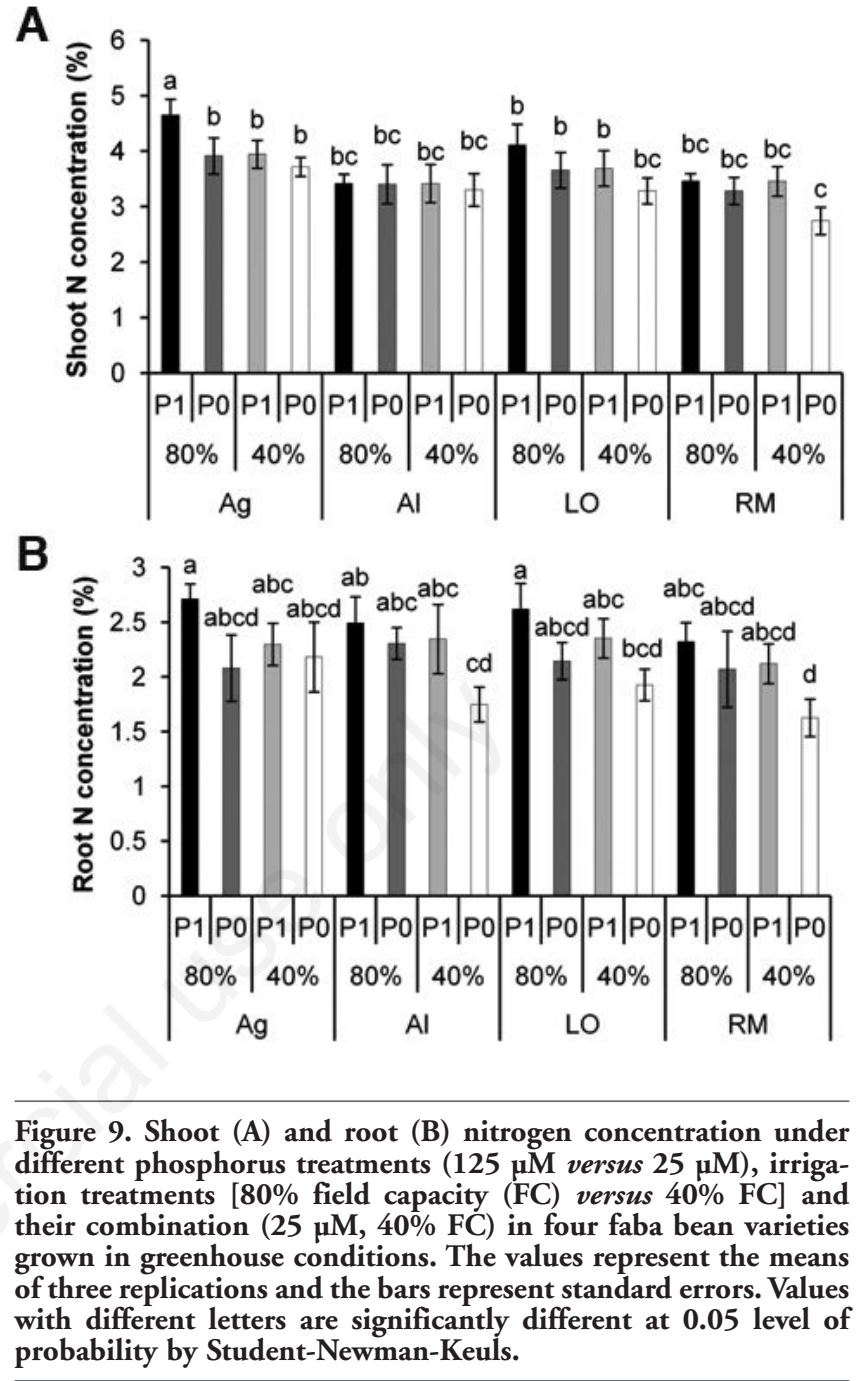

Table 4. Nodule $\mathrm{K}^{+}, \mathrm{Na}^{+}$and $\mathrm{Ca}^{2+}$ concentrations of faba bean varieties under different phosphorus $(\mathrm{P})$ treatments $(\mathrm{P} 1 ; 125 \mu \mathrm{M}$ and $\mathrm{P0} ; 25 \mu \mathrm{M})$ and irrigation treatments $[80 \%$ field capacity $(\mathrm{FC})$ versus $40 \% \mathrm{FC}]$.

\begin{tabular}{|c|c|c|c|c|c|}
\hline Varieties & Irrigation treatment & Phosphorus treatment & $\begin{array}{c}\mathrm{K}^{+} \\
\mathrm{mg} \mathrm{\textrm {g } ^ { - 1 }} \mathrm{DW}\end{array}$ & $\begin{array}{l}\text { utrient conce } \\
\qquad \mathrm{Na}^{+} \\
\mathrm{mg} \mathrm{g}^{-1} \mathrm{DW}\end{array}$ & $\mathrm{Ca}^{2+}$ \\
\hline $\mathrm{Ag}$ & $80 \%$ & P1 & $9.93 \pm 1.03^{\mathrm{d}}$ & $4.41 \pm 0.15^{j}$ & $12.81 \pm 1.25^{\mathrm{i}}$ \\
\hline $\mathrm{Ag}$ & $80 \%$ & $\mathrm{PO}$ & $11.19 \pm 1.96^{\mathrm{d}}$ & $8.92 \pm 0.21^{\mathrm{g}}$ & $14.41 \pm 0.49^{\mathrm{hi}}$ \\
\hline $\mathrm{Ag}$ & $40 \%$ & P1 & $13.33 \pm 1.45^{\mathrm{bc}}$ & $15.35 \pm 1.52^{c}$ & $33.53 \pm 0.90^{\mathrm{b}}$ \\
\hline $\mathrm{Ag}$ & $40 \%$ & $\mathrm{PO}$ & $17.41 \pm 1.14^{\mathrm{a}}$ & $24 \pm 0.08^{\mathrm{a}}$ & $39.93 \pm 0.07^{\mathrm{a}}$ \\
\hline $\mathrm{Al}$ & $80 \%$ & P1 & $4.68 \pm 0.34^{\mathrm{e}}$ & $6.98 \pm 0.11^{\mathrm{i}}$ & $13.76 \pm 0.13^{\mathrm{hi}}$ \\
\hline $\mathrm{Al}$ & $80 \%$ & $\mathrm{PO}$ & $9.65 \pm 1.6^{\mathrm{d}}$ & $11.62 \pm 0.10^{\mathrm{d}}$ & $13.82 \pm 1.48^{\mathrm{hi}}$ \\
\hline $\mathrm{Al}$ & $40 \%$ & P1 & $9.85 \pm 0.78^{\mathrm{d}}$ & $12.05 \pm 0.87^{\mathrm{d}}$ & $14.89 \pm 2.22^{\mathrm{fg}}$ \\
\hline Al & $40 \%$ & $\mathrm{P} 0$ & $14.88 \pm 2.87^{\mathrm{b}}$ & $16.79 \pm 0.18^{b}$ & $26.63 \pm 1.20^{d}$ \\
\hline LO & $80 \%$ & P1 & $10.28 \pm 1.72^{\mathrm{d}}$ & $7.92 \pm 0.08^{\mathrm{h}}$ & $15.46 \pm 0.06^{\mathrm{gh}}$ \\
\hline LO & $80 \%$ & $\mathrm{PO}$ & $11.79 \pm 1.57^{\mathrm{cd}}$ & $10.29 \pm 0.22^{\mathrm{ef}}$ & $17.21 \pm 1.09^{\text {efg }}$ \\
\hline LO & $40 \%$ & Pl & $13.41 \pm 1.45^{\mathrm{bc}}$ & $10.97 \pm 0.02^{\mathrm{de}}$ & $19.42 \pm 0.99 \mathrm{e}$ \\
\hline LO & $40 \%$ & $\mathrm{PO}$ & $16.85 \pm 1.54^{b}$ & $17.35 \pm 0.56^{\mathrm{b}}$ & $27.40 \pm 2.48^{d}$ \\
\hline RM & $80 \%$ & P1 & $5.56 \pm 0.13^{\mathrm{e}}$ & $3.16 \pm 0.23^{\mathrm{k}}$ & $15.87 \pm 0.55^{\mathrm{gh}}$ \\
\hline RM & $80 \%$ & $\mathrm{P} 0$ & $10.59 \pm 0.27^{\mathrm{d}}$ & $9.51 \pm 0.18^{\mathrm{fg}}$ & $17.25 \pm 1.45^{\mathrm{efg}}$ \\
\hline $\mathrm{RM}$ & $40 \%$ & P1 & $11.60 \pm 0.63^{\mathrm{cd}}$ & $10.97 \pm 0.57^{\mathrm{de}}$ & $18.87 \pm 0.70^{\mathrm{ef}}$ \\
\hline RM & $40 \%$ & $\mathrm{PO}$ & $14.12 \pm 0.85^{b}$ & $14.54 \pm 0.69^{c}$ & $30.38 \pm 2.17^{c}$ \\
\hline
\end{tabular}

Values are means of three replicates \pm standard error. DW, dry weight; P, phosphorus; Ag, Aguadulce variety; Al, Alfia variety; LO, Luz d'Otono variety; RM, Reina Mora variety. aj Values with different letters are significantly different at 0.05 level of probability by Student-Newman-Keuls. 
Table 5. Correlation coefficient of the studied parameters.

\begin{tabular}{|c|c|c|c|c|c|}
\hline & RWC & Leaf_area & Shoot_DW & Root_DW & Nodule_DW \\
\hline RWC & 1 & $0.716^{* *}$ & $0.768 * *$ & $0.646^{* *}$ & $0.743^{* *}$ \\
\hline Stomatal conductance & $0.728^{* *}$ & $0.746^{* *}$ & $0.824^{* *}$ & $0.772 * *$ & $0.819 * *$ \\
\hline Leaf water potential & $0.735^{* *}$ & $0.651^{* *}$ & $0.782 * *$ & $0.773^{* *}$ & $0.808^{* *}$ \\
\hline $\mathrm{Fv} / \mathrm{Fm}$ & $0.806^{* *}$ & $0.562 * *$ & $0.727^{* *}$ & $0.747^{* *}$ & $0.726^{* *}$ \\
\hline Electrolyte_leakage & $-0.768 * *$ & $-0.698 * *$ & $-0.848 * *$ & $-0.777^{* *}$ & $-0.855^{* *}$ \\
\hline MDA & $-0.697 * *$ & $-0.670 * *$ & $-0.891^{* *}$ & $-0.759 * *$ & $-0.838^{* *}$ \\
\hline Glycine betaine & $-0.736 * *$ & $-0.732 * *$ & $-0.839 * *$ & $-0.778 * *$ & $-0.907 * *$ \\
\hline N_Shoot & $0.488^{* *}$ & $0.485^{* *}$ & $0.623^{* *}$ & $0.330^{*}$ & $0.510^{* *}$ \\
\hline N_Root & $0.618 * *$ & $0.474^{* *}$ & $0.638 * *$ & $0.538 * *$ & $0.523^{* *}$ \\
\hline P_Shoot & $0.609 * *$ & $0.615^{* *}$ & $0.690^{* *}$ & $0.537 * *$ & $0.613^{* *}$ \\
\hline P_Root & $0.587^{* *}$ & $0.657 * *$ & $0.653^{* *}$ & $0.418^{* *}$ & $0.574^{* *}$ \\
\hline P_Nod & $0.617^{* *}$ & $0.615^{* *}$ & $0.609 * *$ & $0.452^{* *}$ & $0.525^{* *}$ \\
\hline K_Shoot & $-0.740 * *$ & $-0.746^{* *}$ & $-0.693^{* *}$ & $-0.580 * *$ & $-0.756^{* *}$ \\
\hline K_Root & $-0.711^{* *}$ & $-0.653^{* *}$ & $-0.807^{* *}$ & $-0.667^{* *}$ & $-0.818^{* *}$ \\
\hline K_Nod & $-0.623^{* *}$ & $-0.489 * *$ & $-0.574^{* *}$ & $-0.676^{* *}$ & $-0.607^{* *}$ \\
\hline Ca_Shoot & $-0.449 * *$ & $-0.426^{* *}$ & $-0.444^{* *}$ & $-0.529 * *$ & $-0.515^{* *}$ \\
\hline Ca_Root & $-0.517^{* *}$ & $-0.569 * *$ & $-0.624^{* *}$ & $-0.517^{* *}$ & $-0.656^{* *}$ \\
\hline Ca_Nod & $-0.540^{* *}$ & $-0.537^{* *}$ & $-0.681^{* *}$ & $-0.579 * *$ & $-0.710^{* *}$ \\
\hline Na_Shoot & $-0.564^{* *}$ & $-0.423^{* *}$ & $-0.505^{* *}$ & $-0.651^{* *}$ & $-0.563^{* *}$ \\
\hline Na_Root & $-0.640^{* *}$ & $-0.813^{* *}$ & $-0.685^{* *}$ & $-0.378^{* *}$ & $-0.685^{* *}$ \\
\hline Na_Nod & $-0.755^{* *}$ & $-0.665^{* *}$ & $-0.709 * *$ & $-0.609 * *$ & $-0.731^{* *}$ \\
\hline
\end{tabular}

RWC, relative water content; DW, dry weight; MDA, malondialdehyde. The values represent the correlation coefficient ( $\mathrm{n}=48$ ), ${ }^{* *}$ Very significant degree at 0.01 level of probability.

Table 6. Three-ways analyses of variance (ANOVA) of the variety (V), phosphorus treatment (P), irrigation treatment (I) and their interaction for the studied parameters.

\begin{tabular}{|c|c|c|c|c|c|c|c|}
\hline & Depend & ariables & & Indef & ent variable & & \\
\hline & V & P & I & $\mathrm{V} \times \mathrm{P}$ & VxI & PxI & $\mathrm{V} \times \mathrm{P} \times \mathrm{I}$ \\
\hline Shoot_DW & $122.982^{* * *}$ & $433.672^{* * *}$ & $4079.898 * * *$ & $22.836^{* * *}$ & $45.074^{* * *}$ & $48.030^{* * *}$ & $74.654^{* * *}$ \\
\hline Root_DW & $10.088^{* * *}$ & $113.397^{* * *}$ & $238.855^{* * *}$ & $7.827^{* *}$ & $23.586^{* * *}$ & $2.954^{\mathrm{ns}}$ & $21.336^{* * *}$ \\
\hline Nodule_DW & $149.67^{* * *}$ & $222.762^{* * *}$ & $17008.531^{* * *}$ & $0.584^{\mathrm{ns}}$ & $215.141^{* * *}$ & $101.084^{* * *}$ & $2.818^{\text {ns }}$ \\
\hline Leaf_area & $62.439 * * *$ & $411.178^{* * *}$ & $687.169^{* * *}$ & $29.853^{* * *}$ & $43.90^{* * *}$ & $192.728^{* *}$ & $1.875^{\mathrm{ns}}$ \\
\hline RWC & $14.016^{* *}$ & $69.366 * * *$ & $158.207^{* * *}$ & $1.177^{\mathrm{ns}}$ & $1.094^{\mathrm{ns}}$ & $0.761^{\mathrm{ns}}$ & $2.849^{\mathrm{ns}}$ \\
\hline Stomatal_conductance & $38.646^{* * *}$ & $126.727^{* * *}$ & $1424.749^{* * *}$ & $6.094^{* *}$ & $23.710^{* * *}$ & $28.241^{* * *}$ & $3.765^{*}$ \\
\hline Leaf_water_potential & $32.12^{* * *}$ & $652.312^{* * *}$ & $3295.754^{* * *}$ & $47.974^{* * *}$ & $89.621^{* * *}$ & $168.026^{* * *}$ & $57.14 * * *$ \\
\hline $\mathrm{Fv} / \mathrm{Fm}$ & $4.11^{\mathrm{ns}}$ & $42.446^{* * *}$ & $227.449 * * *$ & $4.311^{*}$ & $2.243^{\mathrm{ns}}$ & $26.166^{* * *}$ & $4.492 *$ \\
\hline Electrolyte_leakage & $23.325^{* * *}$ & $69.409 * * *$ & $1160.551^{* * *}$ & $2.462^{\mathrm{ns}}$ & $43.597^{* * *}$ & $6.202^{*}$ & $3.464 *$ \\
\hline MDA & $18.107^{* *}$ & $85.019 * * *$ & $126.003^{* * *}$ & $9.785^{* *}$ & $1.419^{n s}$ & $3.449^{\mathrm{ns}}$ & $1.113^{\mathrm{ns}}$ \\
\hline Glycine_betaine & $18.030 * *$ & $69.223^{* * *}$ & $5754.868 * * *$ & $0.775^{\mathrm{ns}}$ & $18.948 * * *$ & $24.344^{* * *}$ & $0.352^{\mathrm{ns}}$ \\
\hline N_Shoot & $15.43^{* *}$ & $15.663^{* * *}$ & $31.049 * * *$ & $1.178^{\mathrm{ns}}$ & $2.866^{\mathrm{ns}}$ & $0.010^{\text {ns }}$ & $1.399^{n s}$ \\
\hline N_Root & $2.672^{\mathrm{ns}}$ & $41.021^{* * *}$ & $18.19^{* *}$ & $0.092^{\mathrm{ns}}$ & $0.485^{\mathrm{ns}}$ & $0.033^{\mathrm{ns}}$ & $2.663^{\mathrm{ns}}$ \\
\hline P_Shoot & $11.917^{* *}$ & $139.317^{* * *}$ & $88.200^{* * *}$ & $0.098^{\mathrm{ns}}$ & $1.452^{\mathrm{ns}}$ & $7.695^{*}$ & $7.127^{* *}$ \\
\hline P_Root & $21.261^{* * *}$ & $278.361^{* * *}$ & $276.545^{* * *}$ & $10.12^{* *}$ & $24.788 * * *$ & $0.048^{\text {ns }}$ & $1.237^{\mathrm{ns}}$ \\
\hline P_Nodule & $58.853^{* * *}$ & $26.29 .349 * * *$ & $138.465^{* * *}$ & $48.101^{* * *}$ & $27.584^{* * *}$ & $44.587^{* * *}$ & $48.143^{* * *}$ \\
\hline $\mathrm{K}^{+} \_$Shoot & $5.487^{* * *}$ & $46.625^{* * *}$ & $247.359 * * *$ & $9.86^{* *}$ & $3.688^{\text {ns }}$ & $1.347^{\mathrm{ns}}$ & $4.615^{*}$ \\
\hline $\mathrm{K}^{+} \_$Root & $3.521^{\mathrm{ns}}$ & $45.947^{* * *}$ & $279.051^{* * *}$ & $4.709^{*}$ & $4.58^{*}$ & $3.357^{\mathrm{ns}}$ & $3.623^{\mathrm{ns}}$ \\
\hline $\mathrm{K}^{+} \_$Nodule & $18.037^{* *}$ & $133.91^{* * *}$ & $738.451^{* * *}$ & $3.751^{*}$ & $1.762^{\mathrm{ns}}$ & $0.904^{\mathrm{ns}}$ & $3.836^{*}$ \\
\hline $\mathrm{Ca}^{2+}$ _Shoot & $84.824^{* * *}$ & $68.786^{* * *}$ & $231.894^{* * *}$ & $9.810^{* *}$ & $22.089 * * *$ & $0.06^{\mathrm{ns}}$ & $2.514^{\mathrm{ns}}$ \\
\hline $\mathrm{Ca}^{2+}$ _Root & $601.908^{* * *}$ & $163.356^{* * *}$ & $1191.046^{* * *}$ & $5.051^{* *}$ & $72.444 * * *$ & $3.180^{\mathrm{ns}}$ & $9.318^{* *}$ \\
\hline $\mathrm{Ca}^{2+}$ _Nodule & $105.513^{* * *}$ & $376.381^{* * *}$ & $1069.535^{* * *}$ & $3.805^{*}$ & $119.253^{* * *}$ & $219.267^{* * *}$ & $6.259^{* *}$ \\
\hline $\mathrm{Na}^{+}$Shoot & $89.609 * * *$ & $38.651^{* * *}$ & $57.515^{* * *}$ & $1.449^{\mathrm{ns}}$ & $1.191^{\mathrm{ns}}$ & $6.362^{*}$ & $3.459^{*}$ \\
\hline $\mathrm{Na}^{+} \_$Root & $106.567^{* * *}$ & $139.209 * * *$ & $346.99 * * *$ & $6.423^{* *}$ & $41.146^{* * *}$ & $24.804 * * *$ & $10.722^{* * *}$ \\
\hline $\mathrm{Na}^{+}+\_$Nodule & $73.564^{* * *}$ & $1354.923^{* * *}$ & $2075.034^{* * *}$ & $12.289 * * *$ & $136.254^{* * *}$ & $23.889 * * *$ & $35.509 * * *$ \\
\hline
\end{tabular}

Numbers represent F values at 5\% level, *Significant; **very significant; ***highly significant. NS, not significant; V, varieties; P, phosphorus treatment; I, irrigation treatment; DW, dry weight; RWC, relative water content; MDA, malondialdehyde. 
and more negatively correlated to electrolyte leakage $(\mathrm{r}=-0.855)$ and MDA ( $\mathrm{r}=-0.838)$, glycine betaine $(\mathrm{r}=-0.907)$. Thus, from evaluation across the majority of the parameters studied, Aguadulce variety was less affected by the combined effect of water deficit and $\mathrm{P}$ deficiency since it showed the highest shoot and nodule dry weights, the lowest decrease rate of stomatal conductance relative to the control, the highest leaf area and GB accumulation and the lowest electrolyte leakage and MDA under combined stresses in comparison to the other varieties. Hence, it could be considered as the most tolerant variety. On the other hand, Reina Mora variety, based on the same parameters, appeared to be the variety least tolerant to combined water and P limitation.

\section{Discussion}

Plants biomass and yield are the main parameters characterizing agricultural production. However, many environmental stresses such as water deficit and phosphorus limitation cause a series of changes in plants that adversely affect these desirable characters. Many reports have evaluated the individual effect of these abiotic stresses in various plant species including legumes. However, the need for studies on their combined effect lead us to study not only the individual effect of water deficit and P deficiency but also their combined limitation on faba bean defence and metabolism and then examine the performance of four different varieties under drought and/or P stresses. According to our results plant DW (shoot, root and nodule) as well as the leaf area were reduced under water deficit and P limitation in the four studied faba bean varieties, and the reductions were more pronounced under the combined stresses with a significant difference between the varieties. Indeed, the Ag variety was found tolerant compared to others, and this was reflected by low dry biomass reduction and a large foliar area under the combined stressors. According to Antolín et al. (2010) the reduction of plant dry biomass under stress condition is explained by stomatal closure in order to limit plant water loss by transpiration which leads to a reduction in $\mathrm{CO}_{2}$ assimilation and as a result, a reduction in the translocation of assimilates to the nodules. This mechanism also limits the assimilation of $\mathrm{CO}_{2}$ by the plant and results in a reduction of photosynthesis and which leads to growth inhibition. Applied stresses, water deficit or phosphorus limitation, reduced plant relative water content and leaf water potential. This was accompanied with a reduction in the stomatal conductance, and the reductions were more pronounced under the combined stressors in all studied varieties particularly in RM. Moreover, significant positive correlations were observed between leaf relative water content, leaf water potential, stomatal conductance and plant growth (plant biomass and leaves area) (Table 5). Similar results were reported by Mouradi et al. (2016) on alfalfa-rhizobia symbiosis under drought stress. Furthermore, Fujita et al. (2003) showed that phosphorus limitation depressed tomato plant biomass and this was accompanied with a reduction in stomatal conductance. The reduction of photosynthetic activity represented by maximum quantum yield of PS II was explained by the reduction of leaf area and plant water content, under the combined action of both stresses. This was previously mentioned by Li et al. (2006) and by Singh and Reddy (2014) who showed that leaf chlorophyll fluorescence responses to drought and phosphorus deficiency by reducing $F_{v} / F_{m}$. Indeed, the enhanced application of $\mathrm{P}$ improves root development resulting in increased water and nutrients uptake (Wang et al., 2010) and then high leaf water potential, increased stomatal conductance and photosynthetic rate (Waraich et al., 2011). These explained effects of $\mathrm{P}$ on water status, nutrient uptake, stomatal conductance and photosynthetic rate highlight the mechanism that could be related to the response of plants to the shortage of this nutrient element and also to water deficit.

The high correlation of shoot DW to nodule DW ( $\mathrm{r}=0.951)$ shows the importance of the symbiosis for plant growth, as legume-rhizobia symbiosis is sensitive to both water and $\mathrm{P}$ limitation (Sulieman et al., 2013; Nasr Esfahani et al., 2014) and that $20 \%$ of plant total P is assigned to nodule for biological nitrogen fixation (Gunawardena et al., 1992). Moreover, reduced phosphorus application from $125 \mu \mathrm{mol}$ to $25 \mu \mathrm{mol}$ of $\mathrm{P}$ caused a significant decrease of phosphorus assimilation and BNF, particularly when the phosphorus deficiency was combined with drought, reflected by a reduction in plant nitrogen concentration in the four tested faba bean varieties since our plants were grown depending on BNF. Under the combined stresses, the lowest values of both $\mathrm{P}$ and $\mathrm{N}$ clearly reflected the decrease in plant growth and this is related to the influence of low soil moisture on root growth, nutrient mobility in the soil and the plant's ability to get optimal amounts of nutrients (Waraich et al., 2011). The high nodule $\mathrm{P}$ concentration could be explained by the fact that; i) nodules appear to take up P directly from nutrient solution (Al-Niemi et al., 1998); ii) plants use nodules as a sink for P; and also that iii) nodules need high $\mathrm{P}$ concentration for symbiotic nitrogen fixation that is an energy demanding process (Israel, 1993). For nitrogen, the highest values were recorded in the shoots compared to roots; and that could be explained by the efficient translocation of the nitrogen fixed by the plant to the shoot. Bargaz et al. (2011) also reported the harmful effect of phosphorus deficiency on $\mathrm{P}$ and $\mathrm{N}$ concentrations and plant growth of Phaseolus vulgaris while Mouradi et al. (2016) presented this effect on Medicago sativa under drought. Therefore, according to these studies the combined stressors may affect $\mathrm{P}$ and $\mathrm{N}$ concentration and that has been correlated to plants growth, root growth and BNF.

Our results showed that membrane stability parameters, electrolyte leakage and accumulation of MDA, were higher under water stress but the damage was more pronounced under both deficit conditions. The highest accumulation under combined stresses were obtained in RM and according to Jiang and Huang (2001) and Kirnak et al. (2001) the high electrolyte leakage and MDA accumulation is explained by the reduction of relative water content resulting in leaf senescence and subsequently to the reduction of photosynthetic pigment function and chlorophyll. Under combined stresses, Ag variety presented the lowest electrolyte leakage and MDA accumulation reflecting low membrane damage which was correlated by Kabbadj et al. (2017) to a better growth performance under water deficit.

Under osmotic stress, including drought, plants adopt several mechanisms to adjust their internal osmotic potential. Osmoprotectant accumulation including glycine betaine is one of the main adaptive osmotic stress responses in plant (Kido et al., 2019). Under $40 \%$ of substrate field capacity glycine betaine accumulates significantly in the leaves and this was more pronounced under the combined stresses particularly in Ag variety. This accumulation even at low concentrations protects photosynthesis and membrane integrity, stabilizes native structure of proteins and enzymes and detoxifies reactive oxygen radicals produced during stress (Murata et al., 2007; Chen and Murata, 2011). The mechanisms of plants protection by GB under stress for better drought tolerance are related by Bohnert and Jensen (1996) to replacement of water by GB in biochemical reactions, thereby maintaining normal metabolism and then relatively normal growth as shown for Ag variety. Our data showed that drought stress alone or combined with phosphorus deficiency induced not only glycine betaine accumulation but also an increase in 
the concentration of the three plant tissues in some inorganic compounds like $\mathrm{Na}^{+}, \mathrm{K}^{+}$and $\mathrm{Ca}^{2+}$ for which the highest amounts were observed in roots and nodules. Bargaz et al. (2015) stated that osmotic adjustment in legume is achieved by $\mathrm{Na}^{+}$sequestration particularly in nodules. Similarly, under drought stress Farissi et al. (2013) showed that the accumulation of some inorganic compounds particularly $\mathrm{Na}^{+}$and $\mathrm{K}^{+}$is associated drought tolerance in alfalfa. As these organic and inorganic compounds accumulate in response by the plant to the stress while the plant dry weight decreases, a significant negative correlation between these compounds with plant relative water content and DW was found (Table 5). This correlation is explained by the fact that inorganic compounds help plants to mediate stress by their important role in osmotic potential and osmotic adjustment (Silva et al., 2010) through the activation of membrane ATPase enzyme required to drain back the nutrients lost during cell damage and controlling plant metabolism and development (Palta, 1990). In addition, Blum (2017) explained that these organic and inorganic solutes induce a reduction in water potential without complete turgor loss, and thus increase competitiveness and reflect an adaptive trait in support of crop yield under stress condition.

Our experiments, revealed a significant difference between the studied varieties' (Ag, Al, LO, RM) response to water deficit and phosphorus deficiency. This genotypic variation in response could be due to the physiological, anatomical (Gu et al., 2003) and genetic differences and must be exploited to select the more adapted varieties. Available literature indicates variation between drought tolerant and susceptible varieties which may be due to the maintenance of tissue turgor, physiological traits, water uptake from soil and reduction in water loss through stomatal closure (Song et al., 1995; Siddique et al., 2000). Globally, our results showed that of the four varieties tested, $\mathrm{Ag}$ responded the best to the presence of phosphorus especially for nitrogen concentration even under water deficit. This is the effect of biological nitrogen fixation which is a high energy consuming process as the form of ATP requires large amount of phosphorus. In addition, the study of the parameter's correlation and the discussion of their mechanisms effects, suggested that the tolerance of Ag variety could be explained by the fact that $\mathrm{P}$ improved its root system resulting in the improvement of water absorption and nutrient assimilation (Phosphorus and Nitrogen) and the increase of photosynthetic rate and stomatal conductance. Glycine betaine as it accumulated more in $\mathrm{Ag}$ leaves than in RM leaves suggests that the cells may be trying to maintain an osmotic regulation, water potential gradient and tissue hydrostatic pressure under stress.

\section{Conclusions}

In conclusion, among the four faba bean varieties examined in this study, Ag variety was identified as the best performer in terms of plant biomass, leaf water status, membrane stability, osmolyte accumulation and nutrient uptake under water and P deficiency. These responses of faba bean plants to the combined action of both stresses compared to the individual stress factor, demonstrate the existence of considerable defence mechanisms among the varieties to cope with the combination of the two stresses.

The differences highlighted between Vicia faba varieties may be used to track down the genetic differences and the genes involved in the varieties' tolerance to water and phosphorus deficiency and which can also be used in breeding programs. These varieties could also be used for further assessment under field condition and for testing the alteration of both stresses on associated microorganism.

\section{References}

Alghamdi S, Al-Shameri M, Migdadi H, Ammar M, El-Harty E, Khan M, Farooq M, 2015. Physiological and molecular characterization of faba bean (Vicia faba L.) genotypes for adaptation to drought stress. J. Agron. Crop Sci. 201:401-9.

Al-Niemi TS, Kahn ML, McDermott TR, 1998. Phosphorus uptake by bean nodules. Plant Soil. 198:71-8.

Antolín MC, Muro I, Sánchez-Díaz M, 2010. Application of sewage sludge improves growth, photosynthesis and antioxidant activities of nodulated alfalfa plants under drought conditions. Environ. Exp. Bot. 68:75-82.

Argaw A, Mnalku A, 2017. Effectiveness of native Rhizobium on nodulation and yield of faba bean (Vicia faba L.) in Eastern Ethiopia. Arch. Agron. Soil Sci. 63:1390-403.

Bargaz A, Drevon JJ, Oufdou K, Mandri B, Faghire M, Ghoulam C, 2011. Nodule phosphorus requirement and $\mathrm{O} 2$ uptake in common bean genotypes under phosphorus deficiency. Acta Agr. Scand. B-S. P. 61:602-11.

Bargaz A, Zaman-Allah M, Farissi M, Lazali M, Drevon JJ, Maougal RT, Georg C, 2015. Physiological and molecular aspects of tolerance to environmental constraints in grain and forage legumes. Int. J. Mol. Sci. 16:18976-9008.

Blum A, 2017. Osmotic adjustment is a prime drought stress adaptive engine in support of plant production. Plant. Cell. Environ. 40:4-10.

Bohnert HJ, Jensen RG, 1996. Strategies for engineering water-stress tolerance in plants. Trends Biotechnol. 14:89-97.

Chen THH, Murata N, 2011. Glycinebetaine protects plants against abiotic stress: mechanisms and biotechnological applications. Plant. Cell. Environ. 34:1-20.

Farissi M, Bouizgaren A, Faghire M, Bargaz A, Ghoulam C, 2013. Agrophysiological and biochemical properties associated with adaptation of Medicago sativa populations to water deficit. Turk. J. Bot. 37:1166-75.

Food and Agriculture Organization of the United Nations, 2017. FAOSTAT Database. Available from: www.fao.org/faostat/ Accessed: 21 January 2018.

Fujita K, Okada M, Lei K, Ito J, Ohkura K, Adu-Gyamfi JJ, Mohapatra PK, 2003. Effect of P deficiency on photoassimilate partitioning and rhythmic changes in fruit and stem diameter of tomato (Lycopersicon esculentum) during fruit growth. J. Exp. Bot. 54:2519-28.

Ghoulam C, Foursy A, Fares K, 2002. Effects of salt stress on growth, inorganic ions and proline accumulation in relation to osmotic adjustment in five sugar beet cultivars. Environ. Exp. Bot. 47:39-50.

Giri J, 2011. Glycinebetaine and abiotic stress tolerance in plants. Plant Signal. Behav. 6:1746-1751.

Grieve CM, Grattan SR, 1983. Rapid assay for determination of water soluble quaternary ammonium compounds. Plant Soil. 70:303-7.

Gu M, Rom CR, Robbins JA, 2003. Leaf gas exchange and stomatal characteristics of six birch taxa under difference irrigation regimes. Ark. Agr. Exp. Sta. Res. Series. 506:14-16.

Gunawardena SFBN, Danso SKA, Zapata F, 1992. Phosphorus requirement and nitrogen accumulation by three mung bean (Vigna radiata L.) cultivars. Plant Soil. 147:267-74.

Herridge DF, Peoples MB, Boddey RM, 2008. Global inputs of biological nitrogen fixation in agricultural systems. Plant Soil. 311:1-18.

Hinsinger P, 2001. Bioavailability of soil inorganic P in the rhizosphere as affected by root-induced chemical changes: a review. Plant Soil. 237:173-95. 
Israel DW, 1993. Symbiotic dinitrogen fixation and host-plant growth during development of and recovery from phosphorus deficiency. Physiol. Plantarum. 88:294-300.

Jaleel CA, Manivannan P, Wahid A, Farooq M, Somasundaram R, Panneerselvam R, 2009. Drought stress in plants: a review on morphological characteristics and pigments composition. Int. J. Agric. Biol. 11:100-5.

Jemo M, Sulieman S, Bekkaoui F, Olomide OAK, Hashem A, Abd_Allah EF, Alqarawi AA, Tran L-SP, 2017. Comparative analysis of the combined effects of different water and phosphate levels on growth and biological nitrogen fixation of nine cowpea varieties. Front. Plant. Sci. 8:2111.

Jensen ES, Peoples MB, Boddey RM, Gresshoff PM, HauggaardNielsen H, Alves BJR, Morrison MJ, 2012. Legumes for mitigation of climate change and the provision of feedstock for biofuels and biorefineries. A review. Agron. Sustain. Dev. 32:329-64.

Jiang Y, Huang B, 2001. Drought and heat stress injury to two coolseason turfgrasses in relation to antioxidant metabolism and lipid peroxidation. Crop Sci. 41:436-42.

Jifon JL, Syvertsen JP, 2003. Moderate shade can increase net gas exchange and reduce photoinhibition in citrus leaves. Tree Physiol. 23:119-27.

Kabbadj A, Makoudi B, Mouradi M, Pauly N, Frendo P, Ghoulam C, 2017. Physiological and biochemical responses involved in water deficit tolerance of nitrogen-fixing Vicia faba. PLoS One. 12:e0190284.

Kido ÉA, Ferreira-Neto JRC, da Silva MD, Santos VEP, da Silva Filho JLB, Benko-Iseppon AM, 2019. Osmoprotectant-related genes in plants under abiotic stress: expression dynamics, In silico genome mapping and biotechnology. In: M. Hossain, V. Kumar, D. Burritt, M. Fujita, P. Mäkelä (Eds.), Osmoprotectantmediated abiotic stress tolerance in plants. Springer, Cham. 342:1-40.

Kirkby EA, Johnston AE, 2008. Soil and fertilizer phosphorus in relation to crop nutrition. In: White P.J., Hammond J.P. (Eds.), The ecophysiology of plant-phosphorus interactions. Plant Ecophysiology, Vol. 7. Springer, Dordrecht, pp 177-223.

Kirnak H, Cengiz K, David H, Sinan G, 2001. A long-term experiment to study the role of mulches in physiology and macronutrition of strawberry grown under water stress. Aust. J. Agricult. Res. 52:937-43.

Koivunen E, Partanen K, Perttilä S, Palander S, Tuunainen P, Valaja J, 2016. Digestibility and energy value of pea (Pisum sativum L.), faba bean (Vicia faba L.) and blue lupin (narrow-leaf) (Lupinus angustifolius) seeds in broilers. Anim. Feed Sci. Technol. 218:120-7.

Kubure TE, Raghavaiah CV, Hamza I, 2016. Production potential of faba bean (Vicia faba L.) varieties in relation to plant densities and phosphorus nutrition on vertisols of Central Highlands of West Showa Zone, Ethiopia, East Africa. Adv. Crop Sci. Tech. $4: 214$.

Li RH, Guo PG, Baumz M, Grando S, Ceccarelli S, 2006. Evaluation of chlorophyll content and fluorescence parameters as indicators of drought tolerance in barley. Agr. Sci. China. 5:751-7.

Makoudi B, Kabbadj A, Mouradi M, Amenc L, Domergue O, Blair M, Drevon JJ, Ghoulam C, 2018. Phosphorus deficiency increases nodule phytase activity of faba bean-rhizobia symbiosis. Acta Physiol. Plant. 40:63.

Mouradi M, Farissi M, Bouizgaren A, Makoudi B, Kabbadj A, Very AA, Sentenac H, Qaddoury A, Ghoulam C, 2016. Effects of water deficit on growth, nodulation and physiological and biochemical processes in Medicago sativa-rhizobia symbiotic association. Arid Land Res. Manag. 30:193-208.
Mouradi M, Farissi M, Khadraji A, Makoudi B, Ghoulam C, 2018. Biochemical and antioxidant proprieties associated with the adaptation of faba bean (Vicia faba L.) - rhizobia symbiosis to phosphorus deficit. J. Mater. Environ. Sci. 9:1574-81.

Multari S, Stewart D, Russell WR, 2015. Potential of Fava bean as future protein supply to partially replace meat intake in the human diet. Compr. Rev. Food Sci. Food Saf. 14:511-22.

Murata N, Takahashi S, Nishiyama Y, Allakhverdiev SI, 2007. Photoinhibition of photosystem II under environmental stress. B.B.A.-Bioenergetics. 1767:414-21.

Nasr Esfahani M, Sulieman S, Schulze J, Yamaguchi-Shinozaki K, Shinozaki K, Tran LS, 2014. Mechanisms of physiological adjustment of N2 fixation in Cicer arietinum L. (chickpea) during early stages of water deficit: single or multi-factor controls. Plant J. 79:964-80.

Neugschwandtner R, Ziegler K, Kriegner S, Wagentristl H, Kaul HP, 2015. Nitrogen yield and nitrogen fixation of winter faba beans. Acta Agr. Scand. B-S. P. 65:658-66.

Palta JP, 1990. Stress interactions at the cellular and membrane levels. Hort. Sci. 25:1377.

Razmjoo K, Heydarizadeh P, Sabzalian MR, 2008. Effect of salinity and drought stresses on growth parameters and essential oil content of Matricaria chamomile. Int. J. Agric. Biol. 10:451-4.

Šavicka M, Skute N, 2010. Effects of high temperature on malondialdehyde content, superoxide production and growth changes in wheat seedlings (Triticum aestivum L.). Ekologija. 56:26-33.

Shubhra JD, Goswami CL, Munjal R, 2004. Influence of phosphorus application on water relations, biochemical parameters and gum content in cluster bean under water deficit. Biol. Plant. 48:445-8.

Siddique BMR, Hamid A, Islam MS, 2000. Drought stress effect on water relations of wheat. Bot. Bull. Acad. 41:35-9.

Silva EN, Ferreira-Silva SL, Viégas RA, Silveira JAG, 2010. The role of organic and inorganic solutes in the osmotic adjustment of drought-stressed jatropha curcas plants. Environ. Exp. Bot. 69:279-85.

Singh AK, Bharati RC, Manibhushan NC, Pedpati A, 2013. An assessment of faba bean (Vicia faba L.) current status and future prospect. African. J. Agric. Res. 8:6634-41.

Singh SK, Reddy VR, 2014. Combined effects of phosphorus nutrition and elevated carbon dioxide concentration on chlorophyll fluorescence, photosynthesis, and nutrient efficiency of cotton. J. Plant Nutr. Soil Sc. 177:892-902.

Song FB, Dai JY, Gu WB, Li HY, 1995. Effect of water stress on leaf water status in maize. J. Jilin. Agric. Univ. 17:5-9. [in Chinese].

Sulieman S, Ha C Van, Schulze J, Tran, LSP, 2013. Growth and nodulation of symbiotic Medicago truncatula at different levels of phosphorus availability. J. Exp. Bot. 64:2701-12.

Wang W, Vinocur B, Altman A, 2003. Plant responses to drought, salinity and extreme temperatures: towards genetic engineering for stress tolerance. Planta. 218:1-14.

Wang X, Yan X, Liao H, 2010. Genetic improvement for phosphorus efficiency in soybean: a radical approach. Ann. Bot. 106:215-22.

Waraich EA, Ahmad R, Ashraf MY, 2011. Role of mineral nutrition in alleviation of drought stress in plants. Austral. J. Crop Sci. 5:764-77.

Zhu JK, 2002. Salt and drought stress signal transduction in plants. Annu. Rev. Plant Physiol. Plant Mol. Biol. 53:247-73.

Zlatev Z, Lidon FC, 2012. An overview on drought induced changes in plant growth, water relations and photosynthesis. Emir. J. Food Agr. 24:57. 